IZA DP No. 4168

Labour Market Mismatch Among UK Graduates:

An Analysis Using REFLEX Data

Seamus McGuinness

Peter J. Sloane

May 2009 


\title{
Labour Market Mismatch Among UK Graduates: An Analysis Using REFLEX Data
}

\author{
Seamus McGuinness \\ ESRI, Dublin \\ Peter J. Sloane \\ WELMERC, Swansea University \\ and IZA
}

Discussion Paper No. 4168

May 2009

IZA

P.O. Box 7240

53072 Bonn

Germany

Phone: +49-228-3894-0

Fax: +49-228-3894-180

E-mail: iza@iza.org

\begin{abstract}
Any opinions expressed here are those of the author(s) and not those of IZA. Research published in this series may include views on policy, but the institute itself takes no institutional policy positions.

The Institute for the Study of Labor (IZA) in Bonn is a local and virtual international research center and a place of communication between science, politics and business. IZA is an independent nonprofit organization supported by Deutsche Post Foundation. The center is associated with the University of Bonn and offers a stimulating research environment through its international network, workshops and conferences, data service, project support, research visits and doctoral program. IZA engages in (i) original and internationally competitive research in all fields of labor economics, (ii) development of policy concepts, and (iii) dissemination of research results and concepts to the interested public.
\end{abstract}

IZA Discussion Papers often represent preliminary work and are circulated to encourage discussion. Citation of such a paper should account for its provisional character. A revised version may be available directly from the author. 


\section{ABSTRACT \\ Labour Market Mismatch Among UK Graduates: An Analysis Using REFLEX Data}

There is much disagreement in the literature over the extent to which graduates are mismatched in the labour market and the reasons for this. In this paper we utilise the Flexible Professional in the Knowledge Society (REFLEX) data set to cast light on these issues, based on data for UK graduates. REFLEX examines the labour market status of graduates five years after graduation and distinguishes between first and current job, vertical and horizontal mismatch, over/underqualification and over/underskilling as well as including a range of questions on the nature of work organisation and individual competences. We find substantial pay penalties for over-education for both sexes and for overskilling in the case of men only. When both education and skill mismatch variables are included together in the model only overskilling reduces job satisfaction consistently for both sexes. Using job attributes data it appears that the lower wages of the overqualified may in part simply represent a compensating wage differential for positive job attributes, while for men at least there are real costs to being overskilled.

JEL Classification: J24, J31

Keywords: $\quad$ skills, education, job matching, graduates

Corresponding author:

Peter J. Sloane

WELMERC, School of Business and Economics

Swansea University

Richard Price Building

Singleton Park

Swansea, SA2 8PP

United Kingdom

E-mail: p.j.Sloane@swansea.ac.uk 


\section{Introduction}

There is considerable controversy over the extent to which graduates are mismatched or not in the labour market. Studies using measures of overeducation generally find, on the basis of subjective responses to survey questions directed at employees, that a substantial proportion of graduates are employed in jobs for which a degree is not required. Thus, Green and Zhu (2008), using UK Skills Surveys data show that overqualification among graduates rose from $21.2 \%$ in 1992 to $33.2 \%$ in 2006. Battu, Belfield and Sloane (1999) and Dolton and Vignoles (2000), among others, show that overqualified graduates have lower earnings compared to others with the same qualifications, but who are properly matched, though their earnings are higher than those of their matched co-workers. Overqualified workers also report lower job satisfaction than properly matched workers. However, interpretation of such results derived from subjective employee responses to survey questions is not straightforward. Certain jobs may specify a minimum educational requirement and if this is below degree level a graduate may well give a response which indicates he or she is overeducated, though a degree may be the preferred qualification for the job, given sufficient applicants. A further possibility is that educational requirements for particular jobs are rising over time, so that a degree may not have been required when a graduate obtained the job, though it is currently required. Without appropriate questions this may not be picked up. A further problem is that an individual may be overqualified because of low ability for that level of qualification. This may well be consistent with the efficient functioning of the labour market rather than indicating a form of market failure. An alternative interpretation is that certain individuals may have chosen non graduate employment because it offers compensating advantages such as a preferred location or less stressful work. Further, alternative definitions of graduate jobs can produce results which conflict with those in the literature above. Thus, Gottschalk and Hansen (2003), defined a graduate job in terms of whether the proportion of graduates in an occupation exceeded $90 \%$ or, failing that, graduates in that occupation obtained a significant pay premium of at least $10 \%$ over non-graduates. They 
found that the proportion of US graduates in non-graduate jobs was actually declining over time, whereas the earlier overeducation literature had suggested the reverse. Using the same model Grazier, O’Leary and Sloane (2008) obtained a very similar result for the UK. Recent data sets have included questions which enable one to estimate the degree of overskilling and this may be a more appropriate variable for picking up variations in individual ability, since an individual who is overqualified, but not overskilled may be appropriately allocated to a particular occupation.

In this paper we utilise the REFLEX survey in order to attempt to unravel some of the issues identified above. The paper should been seen as extending earlier work. Thus, Allen, Badillo-Amador and van der Velden (2006) used REFEX data from nine countries to show that educational and skill mismatches were rather weakly related. This was confirmed by Green and McIntosh (2007), using UK data. Chevalier (2003) distinguished between those who were in a non-graduate job but satisfied with it (the apparently overeducated ) and those who were similarly matched but not satisfied with it (the genuinely overeducated) . The wage penalty for being overeducated was much lower in the latter case. Chevalier and Lindley (2009) used a 1995 cohort of UK graduates, interviewed in 2002/3, based on four digit occupations to differentiate between graduate and non-graduate jobs. They found that the genuinely overeducated possessed significantly less management and leadership skills than those who were only apparently so. Green and Zhu (2008) distinguished between 'real' and 'formal' overqualification on the basis of whether the overqualification was accompanied by skill underutilisation or not, finding that pay penalties were substantially greater for the real overqualification group than for the formal one.

Using REFLEX we are able to cast further light on these issues by focusing on the UK and making use of the richness of data on graduate employment, which distinguishes between first and current job, vertical and horizontal mismatch, over/underqualification and over/underskilling as well as a range of questions on the nature of work organisation and individual competencies. 


\section{The Data}

The Flexible Professional in the Knowledge Society (REFLEX) project was financed as a Specific Targeted Research Project (STREP) of the European Union's Sixth Framework Programme covering 15 countries. It is limited to graduates in the 1999/2000 academic year, who were interviewed five years later in 2005. We focus on UK graduates only for a number of reasons. First, this allows for a more direct comparison with some of the studies referred to above. Second, the UK is somewhat atypical in having the highest proportion of graduates in any of the countries in the survey failing to utilise their skills. Third, the UK sample consists mainly of those with a bachelors degree, while in many other countries the sample consists mainly or wholly of those with a masters degree. This means that the UK graduates tend to have spent less time in higher education and to be much younger on average at time of graduation than in the other countries (see Brennan (2008)).

With respect to the data used here, we restrict our sample to those individuals currently employed who had studied on a full-time basis while at University. As a result of these exclusions the effective sample falls from 1,578 to 1,123. Individuals were defined as overeducated if they indicated that a below tertiary level of education was most appropriate for the job. Conversely, they were deemed to be undereducated if the most appropriate level of education was below that actually acquired. Overskilling was based on the response to a question asking individuals to rate on a 1 to 5 scale $^{1}$ the extent to which their skills and knowledge were utilised in their work with a response of 1 or 2 deemed consistent with overskilling. Using the same scale, workers were deemed to be underskilled if they responded 4 or 5 to a question indicating that their job demanded more knowledge and skills than they could actually

\footnotetext{
${ }^{1}$ Where 1 was not at all and 5 to a very high extent.
} 
offer. Summary statistics for the UK sample are provided in the appendix; however, some aspects of the data are worth noting at this point. In the UK $36 \%$ felt they were overeducated in their initial job compared to $14 \%$ elsewhere in Europe and 20\% felt that their particular field of study was directly required in their initial job, compared to 29\% elsewhere. Further, 33\% of UK graduates believed that their higher education skills had not been fully utilised in their initial job, compared to $17 \%$ elsewhere. However, when we turn to employment in current job the UK figures for both overeducation and overskilling fell to $14 \%$ compared to $7 \%$ and $10 \%$ elsewhere suggesting that some convergence had taken place. Thus, overall, it is clear that UK graduates still believe that they are less well prepared for employment than other graduates. However, it is unclear to what extent these differences reflect differences in the qualifications obtained and the age at which graduation takes place.

\section{Methodology}

In terms of the methodological approach adopted here, we make an assessment of the extent to which the alternative forms of mismatch are genuine by assessing their impacts on both wages and job satisfaction. Checks are also carried out to ensure that our estimates are not affected by biases relating to either sample selection or unobserved individual heterogeneity. We then go on to exploit a unique aspect of the data to test for compensating differentials before attempting to make some assessment of the specific skill areas where overskilling may occur.

First, we estimate a wage equation of the form

$$
\log \mathrm{w}=\alpha_{1} \mathrm{X}+\alpha_{2} \mathrm{D}^{\mathrm{ED}}+\alpha_{3} \mathrm{D}^{\mathrm{SK}}+\varepsilon_{\mathrm{i}}
$$


Where $\mathrm{X}$ equals a vector of personal and structural characteristics, $\mathrm{D}^{\mathrm{ED}}$ equals over and under-education dummies, $D^{\text {SK }}$ equals over- and underskilling dummies and $\varepsilon_{\mathrm{i}}$ is an iid error term. $\mathrm{D}^{\mathrm{ED}}$ and $\mathrm{D}^{\mathrm{SK}}$ are first entered separately and then jointly to determine the extent to which any negative wage effect is influenced by the presence of the other. These equations are run for the whole sample and separately by gender.

We then adopt a propensity score matching (PSM) model with control and treatment groups to identify any unobserved heterogeneity bias, where the propensity score is defined as the conditional probability of receiving a treatment given certain determining characteristics

$$
\mathrm{p}(\mathrm{X})=\operatorname{Pr}\{\mathrm{D}=1 / \mathrm{X}\}=\mathrm{E}\{\mathrm{D} / \mathrm{X}\}
$$

where $\mathrm{D}$ is a binary term indicating exposure to the treatment and $\mathrm{X}$ is a vector of determining characteristics. On the grounds that both overeducation and overskilling may be associated with unobserved factors, such as lower ability, we exploit the data on first job to ensure that the control group will consist of individuals mismatched in first job but matched in current job. To the extent that either form of mismatch is associated with unobserved factors, these will be constant across the control and treatment groups ensuring the robustness of our estimates. Further sensitivity analysis is then applied to our PSM estimates to ensure that they are free from the effects on individual unobserved heterogeneity bias.

Next, we estimate a probit model of the effect of graduate overeducation or undereducation and graduate overskilling and underskilling on job satisfaction

$$
\mathrm{S}_{\mathrm{i}}^{*}=\beta_{1} \mathrm{X}_{\mathrm{i}}+\beta_{2} \mathrm{D}_{\mathrm{i}}^{\mathrm{ED}}+\beta_{3} \mathrm{D}_{\mathrm{i}}^{\mathrm{SK}}+\mathrm{E}_{1 \mathrm{i}}
$$

where $S_{i}$ is a latent variable which denotes an individual's probability of being satisfied at work based on responses to a job satisfaction question. 
Again the education and skill mismatch variables are initially inserted separately and then jointly.

We then regress on mismatch variables on various job attributes to establish whether individuals are trading off higher earnings for other attributes of employment.

$$
\mathrm{JA}_{\mathrm{i}}=\gamma_{1} \mathrm{X}_{\mathrm{i}}+\gamma_{2} \mathrm{D}_{\mathrm{i}}^{\mathrm{ED}}+\gamma_{3} \mathrm{D}_{\mathrm{i}}^{\mathrm{SK}}+\varepsilon_{2 \mathrm{i}}
$$

Finally, we attempt to establish the relationship between the possession of particular skill competencies and both wages and job satisfaction equations including the skill competency variables.

\section{Results}

Table 1 reports the results from the wage regressions. We estimate four specifications. Specification 1 contains only standard controls, specification 2 includes overeducation and undereducation controls, and specification 3 contains overskilling and underskilling controls with the final specifications including all controls. Specification 4 is then estimated separately for males and females. Turning firstly to specification 1, the model itself is well specified with all covariates behaving according to prior expectations. Males were found to earn a wage premium of nine percent, while faculty effects were limited with only education and agriculture / veterinary graduates earning significantly less than the base case ${ }^{2}$. The returns to a first class or two one degree were 14 and 8 per cent respectively, while respondents who obtained Masters degrees earned 13 per cent more than those who did not. Other variables of interest included a post-graduation unemployment spell, which reduced earnings by 12 per cent and public sector employment, which was associated with a 10 percent penalty. Earnings were found to rise with the number of hours worked, supervisory responsibilities and employment in a large firm. Having more than one employer since graduation tended to depress

\footnotetext{
${ }^{2}$ This consists of graduates from backgrounds such as Engineering, Manufacturing, Construction and Services.
} 
earnings, suggesting that frictional job search activity early in one's career may be costly. The data also contain some interesting controls for horizontal mismatch and course content / prestige. With respect to horizontal mismatch, there was no consistent evidence to suggest that being in a job that was either fully or partially aligned with the subjects studied on the degree programme increased earnings in any way ${ }^{3}$. In terms of course content / prestige, while vocationally orientated degrees or those well known to employers were associated with no wage premiums / penalties, respondents who had graduated from degree programmes that were considered prestigious earned 12 per cent more.

When the overeducation and undereducation variables are added to the model (Specification 2), at almost 40 per cent, there was evidence of a large pay penalty to being overeducated in one's current job. However, no wage effects were evident for overeducation in first job or undereducation in any job. Further, when specification 2 was re-estimated without controls for current over / undereducation, a significant wage penalty of 13 per cent was found for overeducation in first job, confirming that previous and current overeducation are highly correlated. In specification 3 , the pay penalty to being overskilled in current job was, at 22 per cent, almost half that of the comparable overeducation figure. Workers who were underskilled in their current employment earned a 9 per cent premium relative to their matched counterparts, while there was no evidence of any wage effects related to skill mismatch during initial employment. The controls for skill mismatch in first job remained insignificant when the current mismatch variables were dropped from the model, suggesting a somewhat less persistent wage effect. When the model was estimated containing all mismatch controls (Specification 4) the pay penalties associated with overeducation and overskilling in current job fell to 34 and 10 per cent respectively, while the pay premium to underskilling in current job remained unchanged. The magnitude of the adjustment in the overeducation and overskilling pay penalties is somewhat larger than those reported in other studies; however, this is most likely explained by the fact that

\footnotetext{
${ }^{3}$ The 11 per cent premium observed for full horizontal match in specification 1 became statistically insignificant in the more detailed specifications.
} 
the relationship between both subjective variables is much stronger than that reported in these earlier studies, ${ }^{4}$ suggesting the existence of important measurement differences.

When the data were split according to gender the results showed that, while both sexes incurred large wage penalties if overeducated in current job, only males incurred a significant loss as a consequence of current overskilling. Therefore, the results suggest that the pay implications of skill mismatch are much lower than those of educational mismatch and, in the case of UK female graduates, overskilled workers earn a wage comparable to their matched counterparts.

\section{$<$ Insert Table 1 here $>$}

While the evidence from the wage equations suggest that skill mismatch among graduates is potentially much less of a policy concern relative to educational mismatch, some checks are necessary to ensure the reliability of these results. Some previous studies on overeducation have suggested that the pay penalty observed in OLS models is upwardly biased as a consequence of either selection bias (Dolton and Silles, 2002) or unobserved heterogeneity, generally attributed to lower ability levels of mismatched workers (Bauer, 2002, Chevalier, 2003). To ensure the robustness of our estimates we adopt an approach centred on propensity score models (PSM). Under this approach we match individuals with like characteristics and, therefore, deal directly with any concerns relating to sample selection. Furthermore, within our estimation procedure we incorporate each individual's history of job mismatch, so that the control group will consist of individuals who were mismatched in their first job but are now matched. Therefore, to the extent that overeducation or overskilling is associated with unobserved factors, these will be constant across both the control and treatment groups, implying that the PSM estimates will also be robust with respect to unobserved individual heterogeneity bias.

\footnotetext{
${ }^{4}$ Green and McIntosh (2007) find a correlation between overeducation and overskilling of 0.2 compared to 0.48 here.
} 
Table 2 reports the marginal effects from the probit estimations describing overskilling and overeducation in current job respectively. The models are well specified with the overall overskilling and overeducation models reporting pseudo $\mathrm{R}^{2}$ statistics of 0.24 and 0.34 respectively. As expected, mismatch in first job is a strong predictor of mismatch in current job, especially for overeducation. On the whole, the relationship between current and previous mismatch appears stronger for males, particularly those who were overeducated in first employment suggesting higher levels of persistent mismatch among this grouping. With respect to the other covariates, a number of factors were found to influence both education and skill mismatch including horizontal mismatch, a history of unemployment, age, not being employed in a research intensive firm and having completed a non-prestigious degree programme.

The OLS and PSM estimates are compared in Table 3. Post estimation tests were carried out to ensure that the data were sufficient for the control and treatment groups to be balanced on all covariates. Holding constant the variables included in the stage one probits, the PSM estimates are comparable with those of specifications 2 and 3 in table 1. Given that no particular PSM methodology is generally accepted as superior, the Nearest Neighbour (with replacement), Radius and Kernel matching techniques were all used. The results of the PSM estimations align very closely with those of the OLS, suggesting that our original estimates were not affected by either selection or unobserved individual heterogeneity bias.

In order to ensure robustness, further checks with respect to unobserved heterogeneity were achieved by carrying out a sensitivity analysis using Rosenbaum bounds for unobserved heterogeneity at various levels of $\mathrm{e}^{\gamma}$. The bounds allow us to assess the extent to which an unobserved variable must influence the selection process in order to render the matching estimates unreliable. The test again suggests that results are likely to be robust to such effects. For instance, at $\mathrm{e}^{\gamma}=1.7\left(\mathrm{e}^{\gamma}=2\right)$ our overskilling (overeducation) estimate of -24.7 (-37.6) generated by the kernel estimation method was still 
reliable at a 95 per cent level of confidence. The basic intuition here is that even in the event of an unobserved factor increasing the likelihood of overskilling by a factor of 70 per cent, or in excess of 100 per cent in the case of overeducation, our estimate of a wage effect remains reliable at a 95 per cent confidence level ${ }^{5}$. The results seem particularly strong given that sensitivity analysis on the Card and Krueger (1995) minimum wage study found that results become unreliable between $\mathrm{e}^{\gamma}$ values of 1.34 to 1.5 (Rosenbaum, 2002).

\section{< Insert Table 2 here >}

\section{< Insert Table 3 here >}

It is clear that overeducation and overskilling, although correlated, can be considered as distinct events, given that the wage effects of one are not entirely incorporated by those of the other. To explore this matter further, we regress both the educational and skills mismatch variable on a measure of job satisfaction contained within the data ${ }^{6}$. The rationale here is that reductions in job satisfaction will more accurately reflect the extent to which any particular form of mismatch is perceived as a problem for the individual. The existence of wage penalties in themselves do not make the case for policy intervention given the possibility that individuals may choose to trade off lower wages for other aspects of the job, such as increased flexibility, job autonomy, status etc. Previous studies have found that overeducated workers have lower levels of job satisfaction (Battu, Belfield and Sloane (1999), Fleming and Kler (2007). However, for Britain, Green and Zhu (2008) find that overqualification is not a problem for job satisfaction in itself if it is not accompanied by skill mismatch. Similarly, for Spain Badillo Amador, Nicolas and Vila (2008) also find that skill mismatches are a better predictor of job satisfaction than educational mismatches.

\footnotetext{
${ }^{5}$ Results available from the authors.

${ }^{6}$ Respondents were asked to rate how satisfied they were with their current work on a scale of one to 5 where 1 was very dissatisfied and 5 very satisfied. Graduates who responded 4 or 5 were deemed to be satisfied.
} 
The results from the REFLEX data suggest that both overeducation and overskilling, when included in the model independently of each other, lower substantially levels of job satisfaction (Table 3 specifications 1 and 2). When educational mismatch controls only are included in the model, overeducation in current job reduces the probability of job satisfaction by 27 per cent (Specification 2). With respect to skills mismatch, when estimated in a model without educational mismatch controls, overskilling in current job was found to reduce the likelihood of job satisfaction by 30 per cent (Specification 3). When both educational and skills mismatch variables were included in a model we find that only overskilling in current job still reduces the probability of job satisfaction by 25 per cent, while the effect of overeducation declines even more to 17 per cent (Specification 3). Workers who were underskilled in their current job enjoyed higher levels of job satisfaction, with the result more pronounced for females. The results from specification 4 suggest that both overskilling and overeducation can be considered as a policy concern as they reduce both wages and job satisfaction. However, while overskilling has negative consequences for both males and females the overeducation coefficient in the female regression is significant only at the 90 per cent level, casting some doubt on the extent to which education mismatch is considered problematic among female graduates.

The observation that overeducated workers, despite suffering a more significant wage disadvantage relative to overskilled workers, have a higher likelihood of job satisfaction suggests that such workers could be engaging in some level of trade-off between earnings and other aspects of their job. Thus, to some extent overeducation may prove to be a voluntary phenomenon. However, this does not appear to be the case with respect to overskilling, as it is found to lower job satisfaction levels despite having a much smaller impact on earnings.

\section{< Insert Table 4 here >}

The data at hand allow us to explore the compensating differentials issue in more detail. The REFLEX questionnaire asks individuals to rank the extent to 
which the following job characteristics are important to them: work autonomy, job security, learning, earnings, the presentation of new challenges, career prospects, allowing time for leisure activities, social status, societal value and allowing time for family tasks. Workers were then asked to assess the extent to which these job characteristics occurred within their current employment. With respect to testing for compensating differentials, it not sufficient to examine the value that individuals place on certain job characteristics, given that this will not guarantee that the individual is actually employed in a job exhibiting such a factor. Similarly, the fact that a worker is in a job exhibiting various characteristics does not automatically suggest that all such factors were primary drivers in the individual's decision to take the job. To test adequately for compensating differentials we must observe both that a particular job characteristic is of importance to the individual and that the individual is located in a job exhibiting such a characteristic. Consequently, we interact both REFLEX variables to achieve such a measure ${ }^{7}$. We then regress our mismatch variables on the various job attributes to assess the extent to which overeducated workers may be trading off higher earnings for other aspects of employment. However, before proceeding to the econometric analysis, it is worth discussing the distribution of these newly created variables. Somewhat surprisingly, only 7 per cent of respondents placed a high importance on and were in jobs exhibiting high earnings. The graduates in the sample were much more likely to value, and be employed in jobs that offered the opportunity to learn new skills, work autonomously, that had career prospects and societal value. Job security was also of high importance, particularly for females, while 10 per cent of workers placed a high emphasis and were employed in jobs that allowed a balance with family life, with this factor again proving more important for females (Data appendix).

The results from the probit analysis are reported for all workers in tables 5a and 5b, then separately for males (females) in tables 6a and 6b (7a and 7b). The results from the pooled analysis appear intuitively sound (Tables 5a and

\footnotetext{
${ }^{7}$ In both questions respondents are asked to provide a response on a one to five scale where 1 was not at all important (does not apply at all) and 5 very important (applies to a very high extent). The binary variables were based on a response of 5 and the dependent variables in our models were derived from the interaction of these two binary controls.
} 
5b). For instance, males were less likely to place a high emphasis on and be in jobs that were secure or allowed a balanced family life, while individuals who worked more hours tended to be more concerned with achieving higher wages and career progression than balancing family or leisure commitments. Public sector workers placed a high importance on and tended to be in jobs that allowed a family / leisure balance, were secure, had a high social status, career prospects, societal value and presented new challenges. Individuals employed in high-tech / R\&D intensive establishments were more likely to place the emphasis on and be employed in jobs that involved learning, that were career progressive and presented new challenges. With respect to the mismatch variables the results confirm that overeducated workers place a high importance on and are more likely to be employed in jobs that offer security, suggesting that this may be the source of the trade-off explaining average job satisfaction in the face of lower earnings. With respect to overskilling, there was nothing to suggest that such workers were trading off lower pay for other job attributes, the only significant result relating to a lower likelihood of opting for jobs because they presented new challenges. It is worth pointing out that neither the opportunity to learn new skills or improve career prospects were important for mismatched workers, adding further weight to the evidence rejecting explanations of mismatch centred around theories of career advancement (McGuinness and Wooden, 2009). Proponents of the occupational mobility based hypothesis (Rosen 1972; Sicherman and Galor 1990) predict that workers may deliberately enter their preferred profession at a level lower in order to acquire the necessary skills, through on-the-job training and learning, that will enable them to achieve more rapid career progression in the future. Clearly, the evidence presented here refutes this, as none of the controls relating to learning or career progression were significant for either overeducation or overskilling.

Some significant differences were apparent when the models were reestimated according to gender. Overeducated males were found to be more likely to opt for jobs that allow a balance with family life and they tend to place a lower emphasis on high earnings, demonstrating clear evidence of a compensating wage effect. Overskilled males were found to less likely to 
place a high importance on and be employed in jobs that had a societal value or were career progressing (Tables $6 \mathrm{a}$ and $6 \mathrm{~b}$ ). With respect to overeducated females, job security was found to be a key motivating factor underlying job choice. The absence of a significant family balance effect among females is somewhat surprising; however, this may be facilitated primarily through the increased likelihood of public sector employment which tends to be more flexible with respect to achieving a work / life balance. No significant effects were found with respect to overskilled females (Tables 7a and 7b).

\title{
< Insert Table 5a >
}

\author{
$<$ Insert Table 5b >
}

< Insert Table 6a here >

< Insert Table 6b here $>$

< Insert Table 7a here $>$

< Insert Table 7b here >

Finally we attempt to establish the specific skill competencies that, when constrained, lead to lower wages in the case of male graduates and lower levels of job satisfaction for all graduates. The REFLEX questionnaire asks respondents to rank their ability levels in 19 competency areas ${ }^{8}$ on a seven point scale and subsequently to assess the extent to which the competency is required in their current post using a similar rating system. Respondents were also asked to identify their three strongest areas of competency from the list.

\footnotetext{
${ }^{8}$ The competency fields are (1) mastery of own discipline (2) knowledge of other disciplines (3) analytical thinking (4) ability to acquire new knowledge (5) ability to negotiate (6) ability to perform under pressure (7) alertness to new opportunities (8) ability to coordinate activities (9) ability to use time effectively (10) ability to work productively with others (11) ability to mobilise the capabilities of others (12) ability to make your meaning clear to others (13) ability to assert your authority (14) ability to use computers and the internet (15) ability to come up with new ideas and solutions (16) willingness to question your own ideas and others (17) ability to present products and ideas (18) ability to write reports etc. (19) ability to write and speak in a foreign language.
} 
We define an individual as overskilled in a particular area if the competency is identified as a strong point and the level of skill required in the job is two or more rating scores below the level of acquired skill. We re-estimate the job satisfaction and wage equations with these additional variables in order to assess the sensitivity of the overall penalties to the inclusion of the individual mismatch controls.

The re-estimated job satisfaction model is shown in table 8. With respect to the individual overskilling controls in specification 2, the results indicate that overall job satisfaction is lower where graduates are unable to utilise all their field specific knowledge and engage in analytical thinking. However, workers with surplus computer related skills are found to have higher levels of job satisfaction, suggesting that some value is placed on an ability to keep pace with technical progress in a work context. When the general overskilling and overeducation controls are re-introduced into the model, the general job satisfaction penalty of 23 per cent remains unchanged, suggesting that the individual overskilling variables are not effectively identifying the causes of lower job satisfaction. However, the situation alters somewhat when the sample is again split according to gender. The positive return to surplus computer skills appears to be specific to males; furthermore there is evidence of a positive return to surplus language skills among males and, as a consequence of these two effects, the overall overskilling penalty for male graduates actually increases from 25 to 30 per cent when the competency specific controls are included. This suggests that lower male job satisfaction relates either to (a) factors not included in the competency list relating, presumably, to general ability, or (b) the lower wage penalty associated with overskilling. The situation for females is somewhat different, with a negative impact of under used language and field specific competencies reducing the overskilling job satisfaction penalty by approximately 15 per cent. The lack of a negative wage effect suggests that the remainder of the negative female overskilling effect is related to under-utilisation in other unobserved competencies and / or general ability.

\section{< Insert Table 8 here >}




\section{< Insert Table 9 here >}

The re-estimated male wage equation is presented in table 8. There are negative wage effects associated with an inability to use field specific skills and the ability to question ideas. However, when these individual effects are included in the model the overskilling pay penalty falls only marginally. Interestingly, the overeducation pay penalty declines by 20 per cent, demonstrating the importance of these skills in the context of explaining the effects of educational mismatch. Given the comprehensive nature of the controls used in this study, the results suggest that the productivity constraint placed on male graduates and the lower job satisfaction levels experienced by all graduates as a consequence of overskilling are likely to relate to an inability to utilise general intellect as opposed to any specific set of skills.

\section{Conclusions}

There has been a substantial increase in the number of graduates emerging from Higher Education Institutions in the UK and this has raised questions about the ability of the labour market to absorb them. As data based on subjective responses from employed graduates suggest not only that a substantial proportion of graduates are in jobs for which a degree is not required, but also that this proportion has been increasing over time some have expressed concern that the UK may be producing too many graduates. Care must be taken, however, in interpreting these results and our data set, REFLEX enables us not only to distinguish between over-(and under-) education and over-(and under-) skilling, and analyse their effects on both earnings and job satisfaction, but also to consider whether some graduates may have chosen certain jobs which are "non-graduate" because they offer compensating advantages which offset their lower pay.

We find there are large wage penalties for being in a job for which one is currently overeducated and a substantial, but smaller, wage penalty for being 
overskilled. However, only males suffer a significant wage loss as a consequence of current overskilling. These results remain after using a propensity score matching model to control for unobserved heterogeneity. Further, when both educational and skills mismatch variables are included in a job satisfaction question it is overskilling which has the stronger negative effect on job satisfaction, with the overeducation variable being significant only at the $90 \%$ for women. This is suggestive of the presence of a trade-off between earnings and other aspects of employment. Further light is cast on this by utilising a series of questions on job characteristics within the REFLEX data set. We have information both on whether a particular job characteristic is present and, if so, what value the individual employee places on it. Thus, overeducated workers are more likely to be in jobs that offer greater security, which they also tend to value highly, whereas no such factors are present for overskilled workers. Further, over-educated men are more likely to opt for, and value highly, jobs which offered a greater balance with family life and this group also placed a lower emphasis on high earnings. Thus, the balance of evidence points to a trade-off between being employed in jobs with graduate level requirements or selecting those with compensating job attributes. As no such trade-off is found for skill mismatching it is on overskilling that the policy focus should centre as this represents welfare losses both to the individual and the economy as a whole. 
Table 1: Wage equations with overeducation, undereducation, overskilling and underskilling controls

\begin{tabular}{|c|c|c|c|c|c|c|}
\hline VARIABLES & $\begin{array}{c}(1) \\
\text { Model }\end{array}$ & $\begin{array}{c}(2) \\
\text { Model }\end{array}$ & $\begin{array}{c}(3) \\
\text { Model }\end{array}$ & $\begin{array}{c}(4) \\
\text { Model }\end{array}$ & $\begin{array}{c}(5) \\
\text { Males }\end{array}$ & $\begin{array}{c}(6) \\
\text { Females }\end{array}$ \\
\hline Male & $\begin{array}{c}0.09 * * \\
(0.03)\end{array}$ & $\begin{array}{c}0.10^{* * *} \\
(0.03)\end{array}$ & $\begin{array}{c}0.09 * * * \\
(0.03)\end{array}$ & $\begin{array}{c}0.10^{* * *} \\
(0.03)\end{array}$ & - & - \\
\hline Labexp & $\begin{array}{c}0.01^{* * *} \\
(0.00)\end{array}$ & $\begin{array}{c}0.01^{* * *} \\
(0.00)\end{array}$ & $\begin{array}{c}0.01^{* * *} \\
(0.00)\end{array}$ & $\begin{array}{c}0.01^{* * *} \\
(0.00)\end{array}$ & $\begin{array}{c}0.01^{* * * *} \\
(0.00)\end{array}$ & $\begin{array}{c}0.00 * * \\
(0.00)\end{array}$ \\
\hline Age & $\begin{array}{l}-0.00 \\
(0.00)\end{array}$ & $\begin{array}{c}0.00 \\
(0.00)\end{array}$ & $\begin{array}{c}0.00 \\
(0.00)\end{array}$ & $\begin{array}{c}0.00 \\
(0.00)\end{array}$ & $\begin{array}{l}0.01^{*} \\
(0.00)\end{array}$ & $\begin{array}{c}0.00 \\
(0.00)\end{array}$ \\
\hline Education & $\begin{array}{c}-0.15^{* *} \\
(0.07)\end{array}$ & $\begin{array}{c}-0.13^{* *} \\
(0.06)\end{array}$ & $\begin{array}{c}-0.15^{* *} \\
(0.07)\end{array}$ & $\begin{array}{c}-0.14^{* *} \\
(0.06)\end{array}$ & $\begin{array}{l}-0.04 \\
(0.13)\end{array}$ & $\begin{array}{c}-0.17^{* *} \\
(0.08)\end{array}$ \\
\hline Human & $\begin{array}{c}0.02 \\
(0.07)\end{array}$ & $\begin{array}{c}0.03 \\
(0.06)\end{array}$ & $\begin{array}{c}0.02 \\
(0.07)\end{array}$ & $\begin{array}{c}0.03 \\
(0.06)\end{array}$ & $\begin{array}{c}0.14 \\
(0.12)\end{array}$ & $\begin{array}{l}-0.03 \\
(0.08)\end{array}$ \\
\hline Social & $\begin{array}{c}0.04 \\
(0.07)\end{array}$ & $\begin{array}{c}0.06 \\
(0.07)\end{array}$ & $\begin{array}{c}0.04 \\
(0.07)\end{array}$ & $\begin{array}{c}0.05 \\
(0.07)\end{array}$ & $\begin{array}{c}0.14 \\
(0.13)\end{array}$ & $\begin{array}{c}0.01 \\
(0.09)\end{array}$ \\
\hline Science & $\begin{array}{l}-0.05 \\
(0.09)\end{array}$ & $\begin{array}{l}-0.06 \\
(0.09)\end{array}$ & $\begin{array}{l}-0.05 \\
(0.09)\end{array}$ & $\begin{array}{l}-0.06 \\
(0.09)\end{array}$ & $\begin{array}{c}0.10 \\
(0.13)\end{array}$ & $\begin{array}{c}-0.51^{* *} \\
(0.21)\end{array}$ \\
\hline Agvet & $\begin{array}{l}-0.23^{*} \\
(0.12)\end{array}$ & $\begin{array}{l}-0.20 * \\
(0.12)\end{array}$ & $\begin{array}{l}-0.22 * \\
(0.12)\end{array}$ & $\begin{array}{l}-0.20^{*} \\
(0.12)\end{array}$ & $\begin{array}{l}-0.05 \\
(0.16)\end{array}$ & $\begin{array}{l}-0.33 \\
(0.20)\end{array}$ \\
\hline Health & $\begin{array}{c}0.11 \\
(0.09)\end{array}$ & $\begin{array}{c}0.09 \\
(0.09)\end{array}$ & $\begin{array}{c}0.09 \\
(0.09)\end{array}$ & $\begin{array}{c}0.08 \\
(0.09)\end{array}$ & $\begin{array}{c}0.18 \\
(0.17)\end{array}$ & $\begin{array}{c}0.02 \\
(0.10)\end{array}$ \\
\hline Mast & $\begin{array}{c}0.13^{* *} \\
(0.06)\end{array}$ & $\begin{array}{c}0.10 \\
(0.06)\end{array}$ & $\begin{array}{c}0.13^{* *} \\
(0.06)\end{array}$ & $\begin{array}{c}0.10 \\
(0.06)\end{array}$ & $\begin{array}{c}0.11 \\
(0.08)\end{array}$ & $\begin{array}{c}0.08 \\
(0.09)\end{array}$ \\
\hline First & $\begin{array}{c}0.14^{* *} \\
(0.06)\end{array}$ & $\begin{array}{c}0.12 * * \\
(0.06)\end{array}$ & $\begin{array}{c}0.15^{* *} \\
(0.06)\end{array}$ & $\begin{array}{c}0.13^{* *} \\
(0.06)\end{array}$ & $\begin{array}{c}0.23^{* * * *} \\
(0.08)\end{array}$ & $\begin{array}{c}0.04 \\
(0.08)\end{array}$ \\
\hline Twoone & $\begin{array}{c}0.08 * * \\
(0.03)\end{array}$ & $\begin{array}{l}0.06^{*} \\
(0.03)\end{array}$ & $\begin{array}{c}0.08 * * \\
(0.03)\end{array}$ & $\begin{array}{l}0.06^{*} \\
(0.03)\end{array}$ & $\begin{array}{c}0.10^{* *} \\
(0.05)\end{array}$ & $\begin{array}{c}0.02 \\
(0.05)\end{array}$ \\
\hline Unemp & $\begin{array}{c}-0.12 * * * \\
(0.03)\end{array}$ & $\begin{array}{c}-0.09 * * * \\
(0.03)\end{array}$ & $\begin{array}{c}-0.11 * * * \\
(0.03)\end{array}$ & $\begin{array}{c}-0.09 * * * \\
(0.03)\end{array}$ & $\begin{array}{l}-0.08^{*} \\
(0.05)\end{array}$ & $\begin{array}{c}-0.09 * * \\
(0.04)\end{array}$ \\
\hline Supervise & $\begin{array}{c}0.10^{* * * *} \\
(0.03)\end{array}$ & $\begin{array}{c}0.09 * * * \\
(0.03)\end{array}$ & $\begin{array}{c}0.09 * * * \\
(0.03)\end{array}$ & $\begin{array}{c}0.09 * * * \\
(0.03)\end{array}$ & $\begin{array}{c}0.05 \\
(0.05)\end{array}$ & $\begin{array}{c}0.09 * * \\
(0.04)\end{array}$ \\
\hline fieldmatchnow & $\begin{array}{l}0.11^{* *} \\
(0.05)\end{array}$ & $\begin{array}{c}0.00 \\
(0.05)\end{array}$ & $\begin{array}{c}0.05 \\
(0.05)\end{array}$ & $\begin{array}{l}-0.01 \\
(0.05)\end{array}$ & $\begin{array}{l}-0.12 \\
(0.08)\end{array}$ & $\begin{array}{c}0.07 \\
(0.07)\end{array}$ \\
\hline fieldrelatednow & $\begin{array}{c}0.06 \\
(0.04)\end{array}$ & $\begin{array}{l}-0.04 \\
(0.04)\end{array}$ & $\begin{array}{c}0.00 \\
(0.04)\end{array}$ & $\begin{array}{l}-0.05 \\
(0.04)\end{array}$ & $\begin{array}{c}0.01 \\
(0.06)\end{array}$ & $\begin{array}{l}-0.08 \\
(0.06)\end{array}$ \\
\hline fieldmatchjob1 & $\begin{array}{l}-0.07 \\
(0.06)\end{array}$ & $\begin{array}{l}-0.07 \\
(0.06)\end{array}$ & $\begin{array}{l}-0.06 \\
(0.06)\end{array}$ & $\begin{array}{l}-0.06 \\
(0.06)\end{array}$ & $\begin{array}{l}-0.00 \\
(0.09)\end{array}$ & $\begin{array}{l}-0.12 \\
(0.08)\end{array}$ \\
\hline fieldrelatedjob1 & $\begin{array}{c}0.01 \\
(0.04)\end{array}$ & $\begin{array}{l}-0.01 \\
(0.04)\end{array}$ & $\begin{array}{c}0.02 \\
(0.04)\end{array}$ & $\begin{array}{c}0.00 \\
(0.04)\end{array}$ & $\begin{array}{c}-0.15^{* *} \\
(0.06)\end{array}$ & $\begin{array}{c}0.08 \\
(0.06)\end{array}$ \\
\hline Coursemp & $\begin{array}{c}0.02 \\
(0.04)\end{array}$ & $\begin{array}{c}0.02 \\
(0.04)\end{array}$ & $\begin{array}{c}0.02 \\
(0.04)\end{array}$ & $\begin{array}{c}0.02 \\
(0.04)\end{array}$ & $\begin{array}{l}-0.00 \\
(0.05)\end{array}$ & $\begin{array}{c}0.02 \\
(0.05)\end{array}$ \\
\hline courseprest & $\begin{array}{c}0.12^{* * *} \\
(0.03)\end{array}$ & $\begin{array}{c}0.09 * * * \\
(0.03)\end{array}$ & $\begin{array}{c}0.10^{* * *} \\
(0.03)\end{array}$ & $\begin{array}{c}0.08^{* * * *} \\
(0.03)\end{array}$ & $\begin{array}{l}0.08^{*} \\
(0.05)\end{array}$ & $\begin{array}{c}0.11^{* *} \\
(0.04)\end{array}$ \\
\hline coursevoc & $\begin{array}{c}0.04 \\
(0.04)\end{array}$ & $\begin{array}{c}0.02 \\
(0.04)\end{array}$ & $\begin{array}{c}0.02 \\
(0.04)\end{array}$ & $\begin{array}{c}0.01 \\
(0.04)\end{array}$ & $\begin{array}{c}0.00 \\
(0.05)\end{array}$ & $\begin{array}{c}0.04 \\
(0.05)\end{array}$ \\
\hline
\end{tabular}




\begin{tabular}{|c|c|c|c|c|c|c|}
\hline Hours & $\begin{array}{c}0.02 * * * \\
(0.00)\end{array}$ & $\begin{array}{c}0.02 * * * \\
(0.00)\end{array}$ & $\begin{array}{c}0.02 * * * \\
(0.00)\end{array}$ & $\begin{array}{c}0.02 * * * \\
(0.00)\end{array}$ & $\begin{array}{c}0.02 * * * \\
(0.00)\end{array}$ & $\begin{array}{c}0.02 * * * \\
(0.00)\end{array}$ \\
\hline \multirow[t]{2}{*}{ Rdfirm } & 0.03 & 0.01 & 0.02 & 0.01 & -0.03 & 0.03 \\
\hline & $(0.03)$ & $(0.03)$ & $(0.03)$ & $(0.03)$ & $(0.04)$ & $(0.04)$ \\
\hline \multirow[t]{2}{*}{ size5099 } & 0.07 & 0.07 & 0.06 & 0.07 & 0.05 & 0.05 \\
\hline & $(0.06)$ & $(0.06)$ & $(0.06)$ & $(0.06)$ & $(0.09)$ & $(0.08)$ \\
\hline \multirow[t]{2}{*}{ size100249 } & 0.02 & 0.03 & 0.02 & 0.02 & 0.07 & 0.03 \\
\hline & $(0.06)$ & $(0.06)$ & $(0.06)$ & $(0.06)$ & $(0.09)$ & $(0.08)$ \\
\hline \multirow[t]{2}{*}{ size250999 } & $0.09 *$ & $0.10 * *$ & $0.09 *$ & $0.10^{*}$ & 0.06 & 0.08 \\
\hline & $(0.05)$ & $(0.05)$ & $(0.05)$ & $(0.05)$ & $(0.08)$ & $(0.07)$ \\
\hline \multirow[t]{2}{*}{ size1000 } & $0.10 * *$ & $0.12 * * *$ & $0.11 * * *$ & $0.12 * * *$ & $0.22 * * *$ & 0.05 \\
\hline & $(0.04)$ & $(0.04)$ & $(0.04)$ & $(0.04)$ & $(0.06)$ & $(0.05)$ \\
\hline \multirow[t]{2}{*}{ Public } & $-0.10 * * *$ & $-0.10 * * *$ & $-0.11^{* * *}$ & $-0.10^{* * *}$ & $-0.18 * * *$ & $-0.08^{*}$ \\
\hline & $(0.03)$ & $(0.03)$ & $(0.03)$ & $(0.03)$ & $(0.05)$ & $(0.04)$ \\
\hline \multirow[t]{2}{*}{ numemployers } & $-0.01 *$ & -0.01 & $-0.01 *$ & $-0.01^{*}$ & 0.01 & -0.01 \\
\hline & $(0.01)$ & $(0.01)$ & $(0.01)$ & $(0.01)$ & $(0.01)$ & $(0.01)$ \\
\hline \multirow[t]{2}{*}{ overednow } & & $-0.39 * * *$ & & $-0.34^{* * *}$ & $-0.31 * * *$ & $-0.37 * * *$ \\
\hline & & $(0.05)$ & & $(0.05)$ & $(0.07)$ & $(0.08)$ \\
\hline \multirow[t]{2}{*}{ underednow } & & -0.05 & & -0.05 & -0.05 & -0.11 \\
\hline & & $(0.07)$ & & $(0.07)$ & (0.09) & $(0.10)$ \\
\hline \multirow[t]{2}{*}{ Overedjob1 } & & -0.05 & & -0.07 & $-0.11^{*}$ & -0.05 \\
\hline & & $(0.04)$ & & $(0.04)$ & $(0.06)$ & $(0.06)$ \\
\hline \multirow[t]{2}{*}{ underedjob1 } & & 0.03 & & 0.03 & 0.13 & -0.12 \\
\hline & & $(0.09)$ & & $(0.09)$ & $(0.11)$ & $(0.15)$ \\
\hline \multirow[t]{2}{*}{ overskillnow } & & & $-0.22 * * *$ & $-0.10 *$ & $-0.15^{* *}$ & -0.01 \\
\hline & & & $(0.05)$ & $(0.05)$ & $(0.06)$ & $(0.07)$ \\
\hline \multirow[t]{2}{*}{ underskillnow } & & & $0.09 * * *$ & $0.08 * *$ & 0.06 & 0.08 \\
\hline & & & $(0.04)$ & $(0.04)$ & $(0.05)$ & $(0.05)$ \\
\hline \multirow[t]{2}{*}{ overskilljob1 } & & & 0.00 & 0.04 & -0.05 & $0.10^{*}$ \\
\hline & & & $(0.04)$ & $(0.04)$ & $(0.06)$ & $(0.06)$ \\
\hline \multirow[t]{2}{*}{ underskilljob1 } & & & 0.02 & 0.00 & -0.07 & $0.10^{*}$ \\
\hline & & & $(0.04)$ & $(0.04)$ & $(0.06)$ & $(0.06)$ \\
\hline \multirow[t]{2}{*}{ Constant } & $6.44 * * *$ & $6.56 * * *$ & $6.48 * * *$ & $6.55 * * *$ & $6.37 * * *$ & $6.68 * * *$ \\
\hline & $(0.15)$ & $(0.15)$ & $(0.15)$ & $(0.15)$ & $(0.23)$ & $(0.20)$ \\
\hline Observations & 1023 & 1023 & 1023 & 1023 & 392 & 631 \\
\hline R-squared & 0.27 & 0.32 & 0.30 & 0.33 & 0.50 & 0.29 \\
\hline
\end{tabular}


Table 2: Marginal effects from probits - Propensity Score Models

\begin{tabular}{|c|c|c|c|c|c|c|}
\hline \multirow{2}{*}{ VARIABLES } & \multicolumn{3}{|c|}{ Overskilling } & \multicolumn{3}{|c|}{ Overeducation } \\
\hline & All & Males & Females & All & Males & Females \\
\hline \multirow[t]{2}{*}{ overskilljob1 } & $0.11^{* * *}$ & $0.13^{* * *}$ & $0.08^{* *}$ & -0.01 & -0.03 & -0.01 \\
\hline & $(0.03)$ & $(0.05)$ & $(0.03)$ & $(0.02)$ & $(0.03)$ & $(0.02)$ \\
\hline \multirow[t]{2}{*}{ underskilljob1 } & 0.02 & 0.06 & 0.00 & 0.02 & 0.04 & 0.01 \\
\hline & $(0.03)$ & $(0.05)$ & $(0.03)$ & $(0.03)$ & $(0.05)$ & $(0.03)$ \\
\hline \multirow[t]{2}{*}{ overedjob1 } & -0.00 & 0.04 & -0.01 & $0.16^{* * *}$ & $0.22 * * *$ & $0.13^{* * *}$ \\
\hline & $(0.02)$ & $(0.05)$ & $(0.03)$ & $(0.03)$ & $(0.06)$ & $(0.04)$ \\
\hline \multirow[t]{2}{*}{ underedjob1 } & $-0.06^{*}$ & -0.06 & 0.00 & -0.02 & 0.00 & 0.09 \\
\hline & $(0.03)$ & $(0.07)$ & $(0.00)$ & $(0.06)$ & $(0.00)$ & $(0.17)$ \\
\hline \multirow[t]{2}{*}{ male } & $0.04 * *$ & & & 0.02 & & \\
\hline & $(0.02)$ & & & $(0.02)$ & & \\
\hline \multirow[t]{2}{*}{ labexp } & $-0.00 * *$ & -0.00 & -0.00 & -0.00 & -0.00 & -0.00 \\
\hline & $(0.00)$ & $(0.00)$ & $(0.00)$ & $(0.00)$ & $(0.00)$ & $(0.00)$ \\
\hline \multirow[t]{2}{*}{ age } & $0.00 *$ & $0.01 * *$ & -0.00 & $0.00 * *$ & $0.01 * * *$ & 0.00 \\
\hline & $(0.00)$ & $(0.00)$ & $(0.00)$ & $(0.00)$ & $(0.00)$ & $(0.00)$ \\
\hline \multirow[t]{2}{*}{ education } & 0.04 & 0.05 & 0.04 & 0.01 & 0.00 & 0.00 \\
\hline & $(0.05)$ & $(0.12)$ & $(0.05)$ & $(0.03)$ & $(0.08)$ & $(0.03)$ \\
\hline \multirow[t]{2}{*}{ human } & 0.02 & -0.02 & 0.05 & 0.00 & -0.02 & 0.01 \\
\hline & $(0.04)$ & $(0.09)$ & $(0.05)$ & $(0.03)$ & $(0.07)$ & $(0.03)$ \\
\hline \multirow[t]{2}{*}{ social } & 0.03 & -0.00 & 0.06 & 0.02 & 0.02 & 0.01 \\
\hline & $(0.05)$ & $(0.10)$ & $(0.07)$ & $(0.04)$ & $(0.09)$ & $(0.04)$ \\
\hline \multirow[t]{2}{*}{ science } & 0.03 & -0.02 & 0.30 & -0.04 & -0.06 & 0.00 \\
\hline & $(0.07)$ & $(0.09)$ & $(0.29)$ & $(0.03)$ & $(0.05)$ & $(0.00)$ \\
\hline \multirow[t]{2}{*}{ agvet } & 0.05 & 0.01 & 0.00 & 0.09 & -0.02 & $0.52 *$ \\
\hline & $(0.10)$ & $(0.14)$ & $(0.00)$ & $(0.11)$ & $(0.09)$ & $(0.28)$ \\
\hline \multirow[t]{2}{*}{ health } & -0.03 & -0.05 & 0.00 & 0.00 & 0.00 & 0.00 \\
\hline & $(0.06)$ & $(0.10)$ & $(0.00)$ & $(0.00)$ & $(0.00)$ & $(0.00)$ \\
\hline \multirow[t]{2}{*}{ mast } & 0.04 & -0.00 & 0.07 & 0.02 & 0.13 & -0.02 \\
\hline & $(0.04)$ & $(0.07)$ & $(0.07)$ & $(0.04)$ & $(0.11)$ & $(0.03)$ \\
\hline \multirow[t]{2}{*}{ first } & 0.00 & -0.00 & -0.00 & 0.01 & 0.01 & -0.00 \\
\hline & $(0.04)$ & $(0.07)$ & $(0.04)$ & $(0.04)$ & $(0.06)$ & $(0.03)$ \\
\hline \multirow[t]{2}{*}{ twoone } & -0.02 & -0.03 & -0.02 & -0.01 & -0.03 & -0.00 \\
\hline & $(0.02)$ & $(0.04)$ & $(0.02)$ & $(0.02)$ & $(0.03)$ & $(0.02)$ \\
\hline \multirow[t]{2}{*}{ numemployers } & -0.00 & -0.01 & -0.00 & 0.00 & 0.00 & 0.00 \\
\hline & $(0.01)$ & $(0.01)$ & $(0.00)$ & $(0.00)$ & $(0.01)$ & $(0.00)$ \\
\hline unemp & $0.05^{* *}$ & 0.05 & $0.05^{* *}$ & $0.04^{*}$ & 0.03 & $0.04^{*}$ \\
\hline & $(0.02)$ & $(0.04)$ & $(0.03)$ & $(0.02)$ & $(0.03)$ & $(0.02)$ \\
\hline supervise & $-0.04 * *$ & -0.06 & -0.03 & -0.01 & -0.02 & -0.01 \\
\hline & $(0.02)$ & $(0.04)$ & $(0.02)$ & $(0.02)$ & $(0.03)$ & $(0.01)$ \\
\hline fieldmatchnow & $-0.11 * * *$ & $-0.11 * * *$ & $-0.11^{* * *}$ & $-0.10 * * *$ & $-0.09 * * *$ & $-0.10 * * *$ \\
\hline & $(0.02)$ & $(0.03)$ & $(0.02)$ & $(0.02)$ & $(0.03)$ & $(0.02)$ \\
\hline fieldrelatednow & $-0.12 * * *$ & $-0.13^{* * *}$ & $-0.12 * * *$ & $-0.14 * * *$ & $-0.15 * * *$ & $-0.11^{* * *}$ \\
\hline & $(0.02)$ & $(0.04)$ & $(0.02)$ & $(0.02)$ & $(0.04)$ & $(0.03)$ \\
\hline hours & 0.00 & $0.00 *$ & -0.00 & -0.00 & $0.00 *$ & -0.00 \\
\hline & $(0.00)$ & $(0.00)$ & $(0.00)$ & $(0.00)$ & $(0.00)$ & $(0.00)$ \\
\hline coursemp & 0.03 & $0.11^{* *}$ & -0.02 & 0.04 & $0.09 * *$ & 0.00 \\
\hline & $(0.02)$ & $(0.05)$ & $(0.03)$ & $(0.02)$ & $(0.05)$ & $(0.02)$ \\
\hline courseprest & $-0.05^{* * *}$ & $-0.09 * * *$ & $-0.05^{* *}$ & $-0.05^{* * *}$ & $-0.11 * * *$ & $-0.03^{*}$ \\
\hline & $(0.02)$ & $(0.03)$ & $(0.02)$ & $(0.02)$ & $(0.03)$ & $(0.02)$ \\
\hline coursevoc & -0.01 & -0.04 & 0.00 & -0.01 & -0.04 & 0.00 \\
\hline
\end{tabular}


rdfirm

size5099

size100249

size250999

size1000

public

Observations

Pseudo R-squared $\begin{array}{lllll}(0.02) & (0.04) & (0.03) & (0.02) & (0.03)\end{array}$

$\begin{array}{llllll}-0.03 * * & -0.04 & -0.03 & -0.03 * * & -0.04 & -0.02\end{array}$

$\begin{array}{lllll}(0.02) & (0.03) & (0.02) & (0.02) & (0.03)\end{array}$

$\begin{array}{llllll}-0.03 & -0.09 * * & 0.01 & -0.03 & -0.05 & -0.02\end{array}$

$\begin{array}{lllll}(0.03) & (0.04) & (0.05) & (0.02) & (0.04)\end{array}$

$\begin{array}{llllll}-0.03 & -0.04 & -0.04 & -0.03 & -0.06 * * & 0.00\end{array}$

$\begin{array}{llllll}(0.03) & (0.06) & (0.03) & (0.02) & (0.03)\end{array}$

$\begin{array}{llllll}0.01 & 0.01 & 0.01 & 0.01 & 0.01 & -0.00\end{array}$

$\begin{array}{llllll}(0.03) & (0.07) & (0.04) & (0.03) & (0.06) & (0.02)\end{array}$

$\begin{array}{llllll}0.01 & -0.03 & 0.03 & 0.02 & 0.04 & 0.01\end{array}$

$\begin{array}{llllll}(0.02) & (0.04) & (0.03) & (0.02) & (0.04) & (0.02)\end{array}$

$\begin{array}{llllll}-0.03 & -0.03 & -0.02 & -0.01 & 0.00 & -0.01\end{array}$

$\begin{array}{lllll}(0.02) & (0.04) & (0.02) & (0.02) & (0.03)\end{array}$

$\begin{array}{llllll}1056 & 406 & 583 & 994 & 371 & 597\end{array}$

$\begin{array}{llllll}0.23 & 0.24 & 0.25 & 0.34 & 0.38 & 0.36\end{array}$ 
Table 3: OLS \& Propensity Score Model Estimates of Overskilling Wage Effect

\begin{tabular}{|l|c|c|}
\hline & & \\
\hline & Overskiling & Overeducation \\
\hline OLS & $-0.22^{* * *}$ & $-0.39 * * *$ \\
\hline N Neighbour & $-0.26^{* * *}$ & $-0.40^{* * *}$ \\
\hline Radius & $-0.25^{* * *}$ & $-0.40^{* * *}$ \\
\hline Kernal & $-0.25^{* * *}$ & $-0.37 * * *$ \\
\hline
\end{tabular}


Table 4: Probit estimates of Job Satisfaction with overeducation \& overskilling controls

\begin{tabular}{|c|c|c|c|c|c|c|}
\hline VARIABLES & $\begin{array}{l}\text { (1) } \\
\text { All }\end{array}$ & $\begin{array}{l}\text { (2) } \\
\text { All }\end{array}$ & $\begin{array}{l}\text { (3) } \\
\text { All }\end{array}$ & $\begin{array}{l}\text { (4) } \\
\text { All }\end{array}$ & $\begin{array}{c}\text { (5) } \\
\text { Males }\end{array}$ & $\begin{array}{c}(6) \\
\text { Females }\end{array}$ \\
\hline$\overline{\text { male }}$ & $\begin{array}{l}-0.02 \\
(0.03)\end{array}$ & $\begin{array}{l}-0.01 \\
(0.03)\end{array}$ & $\begin{array}{l}-0.01 \\
(0.04)\end{array}$ & $\begin{array}{c}-0.01 \\
(0.04)\end{array}$ & & \\
\hline labexp & $\begin{array}{c}0.00 * * * \\
(0.00)\end{array}$ & $\begin{array}{c}0.00 * * * \\
(0.00)\end{array}$ & $\begin{array}{c}0.00 * * * \\
(0.00)\end{array}$ & $\begin{array}{l}0.00 * * \\
(0.00)\end{array}$ & $\begin{array}{l}0.00 * \\
(0.00)\end{array}$ & $\begin{array}{l}0.00 * \\
(0.00)\end{array}$ \\
\hline age & $\begin{array}{c}-0.00 \\
(0.00)\end{array}$ & $\begin{array}{l}-0.00 \\
(0.00)\end{array}$ & $\begin{array}{l}-0.00 \\
(0.00)\end{array}$ & $\begin{array}{l}-0.00 \\
(0.00)\end{array}$ & $\begin{array}{l}-0.00 \\
(0.00)\end{array}$ & $\begin{array}{l}-0.00 \\
(0.00)\end{array}$ \\
\hline education & $\begin{array}{l}-0.04 \\
(0.07)\end{array}$ & $\begin{array}{l}-0.04 \\
(0.07)\end{array}$ & $\begin{array}{l}-0.03 \\
(0.07)\end{array}$ & $\begin{array}{l}-0.02 \\
(0.07)\end{array}$ & $\begin{array}{l}-0.00 \\
(0.17)\end{array}$ & $\begin{array}{l}-0.02 \\
(0.08)\end{array}$ \\
\hline human & $\begin{array}{l}-0.09 \\
(0.07)\end{array}$ & $\begin{array}{l}-0.08 \\
(0.07)\end{array}$ & $\begin{array}{l}-0.07 \\
(0.07)\end{array}$ & $\begin{array}{l}-0.07 \\
(0.07)\end{array}$ & $\begin{array}{l}-0.05 \\
(0.16)\end{array}$ & $\begin{array}{l}-0.06 \\
(0.08)\end{array}$ \\
\hline social & $\begin{array}{c}0.02 \\
(0.07)\end{array}$ & $\begin{array}{c}0.04 \\
(0.07)\end{array}$ & $\begin{array}{c}0.04 \\
(0.07)\end{array}$ & $\begin{array}{c}0.05 \\
(0.07)\end{array}$ & $\begin{array}{c}0.12 \\
(0.15)\end{array}$ & $\begin{array}{c}0.02 \\
(0.09)\end{array}$ \\
\hline science & $\begin{array}{l}-0.11 \\
(0.10)\end{array}$ & $\begin{array}{l}-0.11 \\
(0.10)\end{array}$ & $\begin{array}{l}-0.08 \\
(0.10)\end{array}$ & $\begin{array}{l}-0.07 \\
(0.10)\end{array}$ & $\begin{array}{l}-0.00 \\
(0.17)\end{array}$ & $\begin{array}{l}-0.29 \\
(0.23)\end{array}$ \\
\hline agvet & $\begin{array}{l}-0.15 \\
(0.13)\end{array}$ & $\begin{array}{l}-0.14 \\
(0.13)\end{array}$ & $\begin{array}{l}-0.15 \\
(0.14)\end{array}$ & $\begin{array}{l}-0.14 \\
(0.14)\end{array}$ & $\begin{array}{l}-0.02 \\
(0.21)\end{array}$ & $\begin{array}{l}-0.23 \\
(0.22)\end{array}$ \\
\hline health & $\begin{array}{l}-0.19 * \\
(0.10)\end{array}$ & $\begin{array}{c}-0.20^{* *} \\
(0.10)\end{array}$ & $\begin{array}{l}-0.19 * \\
(0.10)\end{array}$ & $\begin{array}{l}-0.19 * \\
(0.10)\end{array}$ & $\begin{array}{l}-0.22 \\
(0.22)\end{array}$ & $\begin{array}{l}-0.19 * \\
(0.11)\end{array}$ \\
\hline mast & $\begin{array}{l}-0.06 \\
(0.07)\end{array}$ & $\begin{array}{l}-0.07 \\
(0.07)\end{array}$ & $\begin{array}{l}-0.07 \\
(0.07)\end{array}$ & $\begin{array}{l}-0.07 \\
(0.07)\end{array}$ & $\begin{array}{l}-0.08 \\
(0.11)\end{array}$ & $\begin{array}{l}-0.08 \\
(0.10)\end{array}$ \\
\hline first & $\begin{array}{l}-0.03 \\
(0.06)\end{array}$ & $\begin{array}{l}-0.04 \\
(0.06)\end{array}$ & $\begin{array}{l}-0.04 \\
(0.06)\end{array}$ & $\begin{array}{l}-0.04 \\
(0.06)\end{array}$ & $\begin{array}{l}-0.02 \\
(0.11)\end{array}$ & $\begin{array}{l}-0.04 \\
(0.08)\end{array}$ \\
\hline twoone & $\begin{array}{l}-0.01 \\
(0.03)\end{array}$ & $\begin{array}{l}-0.02 \\
(0.04)\end{array}$ & $\begin{array}{l}-0.01 \\
(0.04)\end{array}$ & $\begin{array}{l}-0.01 \\
(0.04)\end{array}$ & $\begin{array}{c}0.02 \\
(0.06)\end{array}$ & $\begin{array}{l}-0.04 \\
(0.05)\end{array}$ \\
\hline unemp & $\begin{array}{l}-0.05 \\
(0.03)\end{array}$ & $\begin{array}{l}-0.03 \\
(0.03)\end{array}$ & $\begin{array}{l}-0.02 \\
(0.03)\end{array}$ & $\begin{array}{l}-0.02 \\
(0.04)\end{array}$ & $\begin{array}{c}0.02 \\
(0.06)\end{array}$ & $\begin{array}{l}-0.03 \\
(0.04)\end{array}$ \\
\hline supervise & $\begin{array}{c}0.02 \\
(0.03)\end{array}$ & $\begin{array}{c}0.01 \\
(0.03)\end{array}$ & $\begin{array}{c}0.00 \\
(0.03)\end{array}$ & $\begin{array}{c}0.01 \\
(0.03)\end{array}$ & $\begin{array}{l}-0.03 \\
(0.06)\end{array}$ & $\begin{array}{c}0.02 \\
(0.04)\end{array}$ \\
\hline fieldmatchnow & $\begin{array}{c}0.27 * * * \\
(0.04)\end{array}$ & $\begin{array}{c}0.22 * * * \\
(0.05)\end{array}$ & $\begin{array}{c}0.21 * * * \\
(0.05)\end{array}$ & $\begin{array}{c}0.19 * * * \\
(0.05)\end{array}$ & $\begin{array}{c}0.22 * * * \\
(0.08)\end{array}$ & $\begin{array}{c}0.19 * * * \\
(0.06)\end{array}$ \\
\hline fieldrelatednow & $\begin{array}{c}0.11^{* * * *} \\
(0.04)\end{array}$ & $\begin{array}{c}0.04 \\
(0.04)\end{array}$ & $\begin{array}{c}0.04 \\
(0.04)\end{array}$ & $\begin{array}{c}0.01 \\
(0.04)\end{array}$ & $\begin{array}{l}-0.02 \\
(0.08)\end{array}$ & $\begin{array}{c}0.02 \\
(0.06)\end{array}$ \\
\hline fieldmatchjob1 & $\begin{array}{c}-0.22 * * * \\
(0.06)\end{array}$ & $\begin{array}{c}-0.22 * * * \\
(0.06)\end{array}$ & $\begin{array}{c}-0.26^{* * *} \\
(0.06)\end{array}$ & $\begin{array}{c}-0.24 * * * \\
(0.07)\end{array}$ & $\begin{array}{c}-0.28^{* *} \\
(0.11)\end{array}$ & $\begin{array}{c}-0.22 * * \\
(0.09)\end{array}$ \\
\hline fieldrelatedjob1 & $\begin{array}{l}-0.01 \\
(0.04)\end{array}$ & $\begin{array}{l}-0.02 \\
(0.05)\end{array}$ & $\begin{array}{l}-0.04 \\
(0.05)\end{array}$ & $\begin{array}{l}-0.04 \\
(0.05)\end{array}$ & $\begin{array}{c}0.02 \\
(0.08)\end{array}$ & $\begin{array}{l}-0.06 \\
(0.06)\end{array}$ \\
\hline hours & $\begin{array}{l}-0.00 \\
(0.00)\end{array}$ & $\begin{array}{l}-0.00 \\
(0.00)\end{array}$ & $\begin{array}{l}-0.00 \\
(0.00)\end{array}$ & $\begin{array}{l}-0.00 \\
(0.00)\end{array}$ & $\begin{array}{c}0.00 \\
(0.00)\end{array}$ & $\begin{array}{l}-0.00 \\
(0.00)\end{array}$ \\
\hline coursemp & $\begin{array}{c}0.05 \\
(0.04)\end{array}$ & $\begin{array}{c}0.05 \\
(0.04)\end{array}$ & $\begin{array}{c}0.05 \\
(0.04)\end{array}$ & $\begin{array}{c}0.05 \\
(0.04)\end{array}$ & $\begin{array}{c}0.03 \\
(0.06)\end{array}$ & $\begin{array}{c}0.06 \\
(0.05)\end{array}$ \\
\hline courseprest & $\begin{array}{c}0.08 * * * \\
(0.03)\end{array}$ & $\begin{array}{l}0.06^{*} \\
(0.03)\end{array}$ & $\begin{array}{l}0.06^{*} \\
(0.03)\end{array}$ & $\begin{array}{c}0.05 \\
(0.03)\end{array}$ & $\begin{array}{c}0.04 \\
(0.06)\end{array}$ & $\begin{array}{c}0.06 \\
(0.04)\end{array}$ \\
\hline coursevoc & $\begin{array}{c}0.05 \\
(0.04)\end{array}$ & $\begin{array}{c}0.04 \\
(0.04)\end{array}$ & $\begin{array}{c}0.03 \\
(0.04)\end{array}$ & $\begin{array}{c}0.03 \\
(0.04)\end{array}$ & $\begin{array}{c}-0.01 \\
(0.06)\end{array}$ & $\begin{array}{c}0.04 \\
(0.05)\end{array}$ \\
\hline rdfirm & $\begin{array}{c}0.16^{* * *} \\
(0.03)\end{array}$ & $\begin{array}{c}0.15^{* * * *} \\
(0.03)\end{array}$ & $\begin{array}{c}0.14^{* * * *} \\
(0.03)\end{array}$ & $\begin{array}{c}0.14^{* * * *} \\
(0.03)\end{array}$ & $\begin{array}{c}0.19 * * * \\
(0.05)\end{array}$ & $\begin{array}{c}0.11^{* * *} \\
(0.04)\end{array}$ \\
\hline size5099 & -0.04 & -0.04 & -0.05 & -0.06 & 0.06 & -0.12 \\
\hline
\end{tabular}




$\begin{array}{lcccccc}\text { size100249 } & -0.05 & -0.06 & -0.05 & -0.05 & 0.05 & -0.08 \\ \text { size250999 } & (0.06) & (0.07) & (0.07) & (0.07) & (0.11) & (0.08) \\ & -0.11^{* *} & -0.10^{*} & -0.11^{*} & -0.10^{*} & 0.03 & -0.16^{* *} \\ \text { size1000 } & (0.06) & (0.06) & (0.06) & (0.06) & (0.10) & (0.07) \\ & -0.08^{*} & -0.07 & -0.07^{*} & -0.07 & 0.05 & -0.12^{* *} \\ \text { public } & (0.04) & (0.04) & (0.04) & (0.04) & (0.07) & (0.05) \\ & 0.10^{* * *} & 0.10^{* * *} & 0.09^{* * *} & 0.10^{* * *} & 0.11^{*} & 0.10^{* *} \\ \text { numemployers } & (0.03) & (0.03) & (0.03) & (0.03) & (0.06) & (0.04) \\ & -0.00 & -0.00 & -0.01 & -0.00 & 0.03 & -0.01 \\ \text { overednow } & (0.01) & (0.01) & (0.01) & (0.01) & (0.02) & (0.01) \\ & & -0.27^{* * *} & & -0.17^{* * *} & -0.24^{* *} & -0.14^{*} \\ \text { overedjob1 } & & (0.05) & & (0.06) & (0.09) & (0.08) \\ & & -0.01 & & 0.03 & 0.02 & 0.03 \\ \text { underednow } & & (0.04) & & (0.05) & (0.08) & (0.06) \\ & & -0.03 & & -0.05 & -0.12 & 0.01 \\ \text { underedjob1 } & & (0.07) & & (0.08) & (0.12) & (0.10) \\ & & -0.06 & & -0.06 & -0.11 & 0.01 \\ \text { overskillnow } & & (0.10) & & (0.10) & (0.15) & (0.14) \\ & & & -0.30^{* * *} & -0.25^{* * *} & -0.31^{* * *} & -0.20^{* *} \\ \text { overskilljob1 } & & & (0.05) & (0.05) & (0.08) & (0.08) \\ & & & -0.10^{* *} & -0.10^{* *} & -0.12^{*} & -0.10 \\ \text { underskillnow } & & & (0.04) & (0.05) & (0.07) & (0.06) \\ & & & 0.12^{* * *} & 0.11^{* * *} & 0.14^{* *} & 0.08^{*} \\ \text { underskilljob1 } & & & (0.04) & (0.04) & (0.06) & (0.05) \\ \text { Observations } & & & -0.03 & -0.02 & -0.02 & -0.04 \\ \text { R-squared } & & & (0.04) & (0.04) & (0.07) & (0.06) \\ & 1056 & 1056 & 1056 & 1056 & 406 & 650 \\ & 0.08 & 0.10 & 0.13 & 0.13 & 0.20 & 0.12\end{array}$


Table 5a: Job Characteristic Probits - All workers

\begin{tabular}{|c|c|c|c|c|c|}
\hline VARIABLES & $\begin{array}{c}(1) \\
\text { Family }\end{array}$ & $\begin{array}{c}(2) \\
\text { Security }\end{array}$ & $\begin{array}{c}\text { (3) } \\
\text { Earnings }\end{array}$ & $\begin{array}{c}(4) \\
\text { Learning }\end{array}$ & $\begin{array}{c}(5) \\
\text { Status }\end{array}$ \\
\hline male & $\begin{array}{c}-0.04^{* * *} \\
(0.01)\end{array}$ & $\begin{array}{c}-0.08 * * * \\
(0.03)\end{array}$ & $\begin{array}{l}-0.01 \\
(0.01)\end{array}$ & $\begin{array}{l}-0.03 \\
(0.03)\end{array}$ & $\begin{array}{c}0.01 \\
(0.01)\end{array}$ \\
\hline labexp & $\begin{array}{l}-0.00 \\
(0.00)\end{array}$ & $\begin{array}{l}0.00 * \\
(0.00)\end{array}$ & $\begin{array}{c}0.00 \\
(0.00)\end{array}$ & $\begin{array}{c}-0.00 * * \\
(0.00)\end{array}$ & $\begin{array}{l}-0.00 \\
(0.00)\end{array}$ \\
\hline age & $\begin{array}{l}0.00 * * \\
(0.00)\end{array}$ & $\begin{array}{c}0.00 \\
(0.00)\end{array}$ & $\begin{array}{c}0.00 \\
(0.00)\end{array}$ & $\begin{array}{c}0.00 \\
(0.00)\end{array}$ & $\begin{array}{c}0.00 \\
(0.00)\end{array}$ \\
\hline education & $\begin{array}{l}-0.01 \\
(0.03)\end{array}$ & $\begin{array}{c}0.07 \\
(0.06)\end{array}$ & $\begin{array}{c}0.01 \\
(0.03)\end{array}$ & $\begin{array}{l}-0.05 \\
(0.05)\end{array}$ & $\begin{array}{c}0.00 \\
(0.02)\end{array}$ \\
\hline human & $\begin{array}{c}0.01 \\
(0.03)\end{array}$ & $\begin{array}{c}0.01 \\
(0.06)\end{array}$ & $\begin{array}{c}0.03 \\
(0.03)\end{array}$ & $\begin{array}{l}-0.05 \\
(0.05)\end{array}$ & $\begin{array}{c}0.04 \\
(0.03)\end{array}$ \\
\hline social & $\begin{array}{l}-0.01 \\
(0.03)\end{array}$ & $\begin{array}{l}-0.01 \\
(0.06)\end{array}$ & $\begin{array}{l}-0.01 \\
(0.02)\end{array}$ & $\begin{array}{l}-0.05 \\
(0.05)\end{array}$ & $\begin{array}{c}0.02 \\
(0.03)\end{array}$ \\
\hline science & $\begin{array}{c}-0.06 * * * \\
(0.01)\end{array}$ & $\begin{array}{c}0.01 \\
(0.08)\end{array}$ & $\begin{array}{c}0.05 \\
(0.06)\end{array}$ & $\begin{array}{l}-0.03 \\
(0.07)\end{array}$ & $\begin{array}{c}0.05 \\
(0.06)\end{array}$ \\
\hline agvet & $\begin{array}{c}0.06 \\
(0.08)\end{array}$ & $\begin{array}{l}-0.07 \\
(0.09)\end{array}$ & & $\begin{array}{l}-0.13^{*} \\
(0.07)\end{array}$ & \\
\hline health & $\begin{array}{l}-0.02 \\
(0.03)\end{array}$ & $\begin{array}{c}0.04 \\
(0.08)\end{array}$ & & $\begin{array}{c}0.03 \\
(0.08)\end{array}$ & $\begin{array}{l}-0.00 \\
(0.03)\end{array}$ \\
\hline mast & $\begin{array}{c}0.02 \\
(0.04)\end{array}$ & $\begin{array}{c}-0.11^{* *} \\
(0.04)\end{array}$ & $\begin{array}{c}-0.05^{* * *} \\
(0.01)\end{array}$ & $\begin{array}{c}0.00 \\
(0.05)\end{array}$ & $\begin{array}{c}-0.02 * * \\
(0.01)\end{array}$ \\
\hline first & $\begin{array}{c}0.04 \\
(0.04)\end{array}$ & $\begin{array}{l}-0.08^{*} \\
(0.04)\end{array}$ & $\begin{array}{l}-0.00 \\
(0.02)\end{array}$ & $\begin{array}{c}0.01 \\
(0.05)\end{array}$ & $\begin{array}{c}-0.03 * * * \\
(0.01)\end{array}$ \\
\hline twoone & $\begin{array}{c}0.00 \\
(0.02)\end{array}$ & $\begin{array}{c}-0.07 * * \\
(0.03)\end{array}$ & $\begin{array}{l}-0.02 \\
(0.01)\end{array}$ & $\begin{array}{c}-0.07 * * \\
(0.03)\end{array}$ & $\begin{array}{l}-0.01 \\
(0.01)\end{array}$ \\
\hline unemp & $\begin{array}{l}-0.00 \\
(0.02)\end{array}$ & $\begin{array}{l}-0.06^{*} \\
(0.03)\end{array}$ & $\begin{array}{l}-0.01 \\
(0.01)\end{array}$ & $\begin{array}{l}-0.04 \\
(0.03)\end{array}$ & $\begin{array}{c}0.01 \\
(0.01)\end{array}$ \\
\hline supervise & $\begin{array}{l}-0.03^{*} \\
(0.01)\end{array}$ & $\begin{array}{c}0.04 \\
(0.03)\end{array}$ & $\begin{array}{c}0.01 \\
(0.01)\end{array}$ & $\begin{array}{l}-0.01 \\
(0.03)\end{array}$ & $\begin{array}{l}-0.00 \\
(0.01)\end{array}$ \\
\hline fieldmatchnow & $\begin{array}{c}0.01 \\
(0.02)\end{array}$ & $\begin{array}{c}0.07 \\
(0.04)\end{array}$ & $\begin{array}{c}0.04 \\
(0.03)\end{array}$ & $\begin{array}{l}0.08^{*} \\
(0.04)\end{array}$ & $\begin{array}{c}0.01 \\
(0.02)\end{array}$ \\
\hline fieldrelatednow & $\begin{array}{c}0.01 \\
(0.02)\end{array}$ & $\begin{array}{c}0.01 \\
(0.04)\end{array}$ & $\begin{array}{l}-0.00 \\
(0.02)\end{array}$ & $\begin{array}{c}0.01 \\
(0.03)\end{array}$ & $\begin{array}{c}0.01 \\
(0.01)\end{array}$ \\
\hline hours & $\begin{array}{c}-0.00 * * \\
(0.00)\end{array}$ & $\begin{array}{c}0.00 \\
(0.00)\end{array}$ & $\begin{array}{c}0.00 * * * \\
(0.00)\end{array}$ & $\begin{array}{c}0.00 \\
(0.00)\end{array}$ & $\begin{array}{c}0.00 \\
(0.00)\end{array}$ \\
\hline coursemp & $\begin{array}{c}0.02 \\
(0.02)\end{array}$ & $\begin{array}{l}-0.02 \\
(0.03)\end{array}$ & $\begin{array}{l}0.03 * \\
(0.02)\end{array}$ & $\begin{array}{l}-0.00 \\
(0.03)\end{array}$ & $\begin{array}{l}0.03^{*} \\
(0.01)\end{array}$ \\
\hline courseprest & $\begin{array}{c}0.02 \\
(0.01)\end{array}$ & $\begin{array}{c}0.02 \\
(0.03)\end{array}$ & $\begin{array}{c}0.01 \\
(0.01)\end{array}$ & $\begin{array}{c}0.01 \\
(0.03)\end{array}$ & $\begin{array}{c}0.00 \\
(0.01)\end{array}$ \\
\hline coursevoc & $\begin{array}{c}0.01 \\
(0.02)\end{array}$ & $\begin{array}{c}0.03 \\
(0.03)\end{array}$ & $\begin{array}{l}-0.01 \\
(0.01)\end{array}$ & $\begin{array}{l}-0.02 \\
(0.03)\end{array}$ & $\begin{array}{l}-0.00 \\
(0.01)\end{array}$ \\
\hline rdfirm & $\begin{array}{l}-0.01 \\
(0.01)\end{array}$ & $\begin{array}{l}-0.00 \\
(0.03)\end{array}$ & $\begin{array}{c}0.01 \\
(0.01)\end{array}$ & $\begin{array}{c}0.08 * * * \\
(0.03)\end{array}$ & $\begin{array}{c}0.00 \\
(0.01)\end{array}$ \\
\hline size5099 & $\begin{array}{c}0.01 \\
(0.02)\end{array}$ & $\begin{array}{c}0.08 \\
(0.06)\end{array}$ & $\begin{array}{c}0.03 \\
(0.03)\end{array}$ & $\begin{array}{c}0.04 \\
(0.05)\end{array}$ & $\begin{array}{c}0.05 \\
(0.03)\end{array}$ \\
\hline size100249 & -0.03 & 0.02 & $-0.03 *$ & -0.04 & 0.01 \\
\hline
\end{tabular}




\begin{tabular}{lccccc} 
& $(0.02)$ & $(0.05)$ & $(0.02)$ & $(0.05)$ & $(0.02)$ \\
size250999 & $-0.05^{* * *}$ & -0.02 & 0.01 & -0.04 & -0.01 \\
size1000 & $(0.01)$ & $(0.04)$ & $(0.02)$ & $(0.04)$ & $(0.01)$ \\
public & $-0.05^{* * *}$ & $-0.07^{* *}$ & -0.01 & -0.05 & $-0.03^{*}$ \\
& $(0.02)$ & $(0.03)$ & $(0.02)$ & $(0.03)$ & $(0.01)$ \\
numemployers & $0.04^{* * *}$ & $0.14^{* * *}$ & 0.00 & $0.07 * *$ & $0.04^{* * *}$ \\
& $(0.02)$ & $(0.03)$ & $(0.01)$ & $(0.03)$ & $(0.01)$ \\
overskillnow & $0.00^{* *}$ & $-0.03^{* * *}$ & -0.01 & -0.00 & -0.01 \\
& $(0.00)$ & $(0.01)$ & $(0.00)$ & $(0.01)$ & $(0.00)$ \\
overednow & -0.00 & -0.03 & -0.02 & $-0.07^{*}$ & $-0.03^{* * *}$ \\
& $(0.02)$ & $(0.04)$ & $(0.02)$ & $(0.04)$ & $(0.01)$ \\
Observations & 0.05 & $0.11^{* *}$ & -0.02 & -0.06 & 0.03 \\
Pseudo R-squared & $(0.04)$ & $(0.05)$ & $(0.02)$ & $(0.04)$ & $(0.03)$ \\
\hline
\end{tabular}


Table 5b: Job Characteristic Probits - All Workers

\begin{tabular}{|c|c|c|c|c|c|}
\hline VARIABLES & $\begin{array}{c}(1) \\
\text { Useful }\end{array}$ & $\begin{array}{c}(2) \\
\text { Leisure } \\
\end{array}$ & $\begin{array}{c}(3) \\
\text { Career }\end{array}$ & $\begin{array}{c}(4) \\
\text { Autonom }\end{array}$ & $\begin{array}{c}(5) \\
\text { Chall } \\
\end{array}$ \\
\hline male & $\begin{array}{l}-0.04 \\
(0.03)\end{array}$ & $\begin{array}{l}-0.02 \\
(0.02)\end{array}$ & $\begin{array}{c}0.03 \\
(0.03)\end{array}$ & $\begin{array}{l}-0.03 \\
(0.02)\end{array}$ & $\begin{array}{c}-0.06^{* *} \\
(0.03)\end{array}$ \\
\hline labexp & $\begin{array}{c}-0.00 * * \\
(0.00)\end{array}$ & $\begin{array}{c}0.00 \\
(0.00)\end{array}$ & $\begin{array}{c}0.00 \\
(0.00)\end{array}$ & $\begin{array}{l}-0.00 \\
(0.00)\end{array}$ & $\begin{array}{l}-0.00 \\
(0.00)\end{array}$ \\
\hline age & $\begin{array}{c}0.00 \\
(0.00)\end{array}$ & $\begin{array}{l}-0.00 \\
(0.00)\end{array}$ & $\begin{array}{l}-0.00 \\
(0.00)\end{array}$ & $\begin{array}{c}0.00 * * * \\
(0.00)\end{array}$ & $\begin{array}{c}0.00 \\
(0.00)\end{array}$ \\
\hline education & $\begin{array}{l}-0.03 \\
(0.04)\end{array}$ & $\begin{array}{c}0.05 \\
(0.06)\end{array}$ & $\begin{array}{c}0.03 \\
(0.05)\end{array}$ & $\begin{array}{l}-0.04 \\
(0.04)\end{array}$ & $\begin{array}{l}-0.01 \\
(0.05)\end{array}$ \\
\hline human & $\begin{array}{l}-0.05 \\
(0.04)\end{array}$ & $\begin{array}{c}0.06 \\
(0.05)\end{array}$ & $\begin{array}{c}0.05 \\
(0.05)\end{array}$ & $\begin{array}{c}0.01 \\
(0.05)\end{array}$ & $\begin{array}{c}0.01 \\
(0.05)\end{array}$ \\
\hline social & $\begin{array}{l}-0.06 \\
(0.04)\end{array}$ & $\begin{array}{c}0.05 \\
(0.06)\end{array}$ & $\begin{array}{c}0.01 \\
(0.05)\end{array}$ & $\begin{array}{l}-0.02 \\
(0.05)\end{array}$ & $\begin{array}{l}-0.01 \\
(0.06)\end{array}$ \\
\hline science & $\begin{array}{l}-0.05 \\
(0.06)\end{array}$ & $\begin{array}{c}0.02 \\
(0.08)\end{array}$ & $\begin{array}{l}-0.00 \\
(0.06)\end{array}$ & $\begin{array}{l}-0.08 \\
(0.05)\end{array}$ & $\begin{array}{c}0.02 \\
(0.08)\end{array}$ \\
\hline agvet & $\begin{array}{c}-0.12 * * * \\
(0.04)\end{array}$ & $\begin{array}{l}-0.02 \\
(0.09)\end{array}$ & $\begin{array}{l}-0.08 \\
(0.06)\end{array}$ & $\begin{array}{l}-0.03 \\
(0.08)\end{array}$ & \\
\hline health & $\begin{array}{l}-0.00 \\
(0.06)\end{array}$ & $\begin{array}{l}-0.06 \\
(0.05)\end{array}$ & $\begin{array}{l}-0.03 \\
(0.05)\end{array}$ & $\begin{array}{c}0.01 \\
(0.06)\end{array}$ & $\begin{array}{c}0.03 \\
(0.07)\end{array}$ \\
\hline mast & $\begin{array}{l}-0.00 \\
(0.05)\end{array}$ & $\begin{array}{l}-0.05 \\
(0.04)\end{array}$ & $\begin{array}{c}-0.07 * * \\
(0.03)\end{array}$ & $\begin{array}{c}0.02 \\
(0.05)\end{array}$ & $\begin{array}{l}-0.03 \\
(0.05)\end{array}$ \\
\hline first & $\begin{array}{c}0.04 \\
(0.05)\end{array}$ & $\begin{array}{c}0.01 \\
(0.04)\end{array}$ & $\begin{array}{l}-0.04 \\
(0.03)\end{array}$ & $\begin{array}{c}0.06 \\
(0.05)\end{array}$ & $\begin{array}{c}0.04 \\
(0.05)\end{array}$ \\
\hline twoone & $\begin{array}{c}0.03 \\
(0.03)\end{array}$ & $\begin{array}{l}-0.02 \\
(0.03)\end{array}$ & $\begin{array}{c}-0.06 * * * \\
(0.02)\end{array}$ & $\begin{array}{l}-0.02 \\
(0.03)\end{array}$ & $\begin{array}{l}-0.03 \\
(0.03)\end{array}$ \\
\hline unemp & $\begin{array}{l}-0.00 \\
(0.03)\end{array}$ & $\begin{array}{c}0.03 \\
(0.03)\end{array}$ & $\begin{array}{l}-0.04^{*} \\
(0.02)\end{array}$ & $\begin{array}{c}0.00 \\
(0.02)\end{array}$ & $\begin{array}{l}-0.05^{*} \\
(0.03)\end{array}$ \\
\hline supervise & $\begin{array}{c}0.02 \\
(0.02)\end{array}$ & $\begin{array}{l}-0.04^{*} \\
(0.02)\end{array}$ & $\begin{array}{c}0.01 \\
(0.02)\end{array}$ & $\begin{array}{l}0.04^{*} \\
(0.02)\end{array}$ & $\begin{array}{c}0.02 \\
(0.02)\end{array}$ \\
\hline fieldmatchnow & $\begin{array}{l}-0.01 \\
(0.03)\end{array}$ & $\begin{array}{c}0.04 \\
(0.04)\end{array}$ & $\begin{array}{c}0.08 * * \\
(0.04)\end{array}$ & $\begin{array}{l}-0.00 \\
(0.03)\end{array}$ & $\begin{array}{c}0.04 \\
(0.04)\end{array}$ \\
\hline fieldrelatednow & $\begin{array}{c}-0.07 * * \\
(0.03)\end{array}$ & $\begin{array}{c}0.00 \\
(0.03)\end{array}$ & $\begin{array}{c}0.02 \\
(0.03)\end{array}$ & $\begin{array}{l}-0.01 \\
(0.03)\end{array}$ & $\begin{array}{l}-0.02 \\
(0.03)\end{array}$ \\
\hline hours & $\begin{array}{l}-0.00 \\
(0.00)\end{array}$ & $\begin{array}{c}-0.00 * * \\
(0.00)\end{array}$ & $\begin{array}{l}0.00^{*} \\
(0.00)\end{array}$ & $\begin{array}{l}-0.00 \\
(0.00)\end{array}$ & $\begin{array}{c}0.00 \\
(0.00)\end{array}$ \\
\hline coursemp & $\begin{array}{c}-0.06^{* *} \\
(0.03)\end{array}$ & $\begin{array}{l}-0.01 \\
(0.03)\end{array}$ & $\begin{array}{c}0.06 * * \\
(0.03)\end{array}$ & $\begin{array}{c}0.06^{* *} \\
(0.03)\end{array}$ & $\begin{array}{c}0.04 \\
(0.03)\end{array}$ \\
\hline courseprest & $\begin{array}{l}0.04^{*} \\
(0.02)\end{array}$ & $\begin{array}{c}0.01 \\
(0.02)\end{array}$ & $\begin{array}{c}0.01 \\
(0.02)\end{array}$ & $\begin{array}{l}-0.04 \\
(0.02)\end{array}$ & $\begin{array}{c}0.03 \\
(0.03)\end{array}$ \\
\hline coursevoc & $\begin{array}{l}-0.03 \\
(0.03)\end{array}$ & $\begin{array}{l}-0.01 \\
(0.03)\end{array}$ & $\begin{array}{l}-0.02 \\
(0.03)\end{array}$ & $\begin{array}{c}0.01 \\
(0.03)\end{array}$ & $\begin{array}{c}-0.06^{* *} \\
(0.03)\end{array}$ \\
\hline rdfirm & $\begin{array}{c}0.01 \\
(0.02)\end{array}$ & $\begin{array}{l}-0.01 \\
(0.02)\end{array}$ & $\begin{array}{l}0.04^{*} \\
(0.02)\end{array}$ & $\begin{array}{c}0.03 \\
(0.02)\end{array}$ & $\begin{array}{c}0.09 * * * \\
(0.03)\end{array}$ \\
\hline size5099 & $\begin{array}{c}0.04 \\
(0.05)\end{array}$ & $\begin{array}{c}0.05 \\
(0.05)\end{array}$ & $\begin{array}{c}0.06 \\
(0.05)\end{array}$ & $\begin{array}{c}0.06 \\
(0.05)\end{array}$ & $\begin{array}{l}0.09 * \\
(0.05)\end{array}$ \\
\hline
\end{tabular}




\begin{tabular}{lccccc} 
size100249 & -0.01 & $0.10^{*}$ & -0.03 & 0.02 & -0.02 \\
size250999 & $(0.04)$ & $(0.06)$ & $(0.04)$ & $(0.05)$ & $(0.05)$ \\
& $-0.06^{* *}$ & -0.02 & -0.03 & -0.00 & -0.06 \\
size1000 & $(0.03)$ & $(0.04)$ & $(0.03)$ & $(0.04)$ & $(0.04)$ \\
& $-0.11^{* * *}$ & 0.05 & -0.02 & -0.01 & -0.03 \\
public & $(0.03)$ & $(0.03)$ & $(0.03)$ & $(0.03)$ & $(0.03)$ \\
& $0.21^{* * *}$ & $0.05^{* *}$ & $0.06^{* * *}$ & 0.03 & $0.08^{* * *}$ \\
numemployers & $(0.03)$ & $(0.02)$ & $(0.02)$ & $(0.02)$ & $(0.03)$ \\
& 0.00 & -0.00 & 0.00 & 0.00 & 0.00 \\
overskillnow & $(0.00)$ & $(0.01)$ & $(0.00)$ & $(0.00)$ & $(0.00)$ \\
& -0.04 & 0.01 & -0.04 & 0.00 & 0.02 \\
overednow & $(0.04)$ & $(0.04)$ & $(0.03)$ & $(0.04)$ & $(0.04)$ \\
& 0.01 & 0.05 & -0.02 & -0.03 & -0.06 \\
& $(0.04)$ & $(0.04)$ & $(0.04)$ & $(0.04)$ & $(0.04)$ \\
Observations & & & & & \\
Pseudo R-squared & 1056 & 1056 & 1056 & 1056 & 1034 \\
\hline
\end{tabular}


Table 6a: Job Characteristic Probits - Males

\begin{tabular}{|c|c|c|c|c|c|}
\hline VARIABLES & $\begin{array}{c}(1) \\
\text { Family }\end{array}$ & $\begin{array}{c}(2) \\
\text { Security }\end{array}$ & $\begin{array}{c}\text { (3) } \\
\text { Earnings }\end{array}$ & $\begin{array}{c}\text { (4) } \\
\text { Learning }\end{array}$ & $\begin{array}{l}(5) \\
\text { Status }\end{array}$ \\
\hline labexp & $\begin{array}{c}0.00 \\
(0.00)\end{array}$ & $\begin{array}{c}0.00 * * \\
(0.00)\end{array}$ & $\begin{array}{c}0.00 * * \\
(0.00)\end{array}$ & $\begin{array}{c}-0.00 * * \\
(0.00)\end{array}$ & $\begin{array}{l}-0.00 \\
(0.00)\end{array}$ \\
\hline age & $\begin{array}{c}0.00 \\
(0.00)\end{array}$ & $\begin{array}{c}0.00 \\
(0.00)\end{array}$ & $\begin{array}{l}-0.00 \\
(0.00)\end{array}$ & $\begin{array}{l}-0.00 \\
(0.00)\end{array}$ & $\begin{array}{c}0.00 \\
(0.00)\end{array}$ \\
\hline education & $\begin{array}{c}0.00 \\
(0.02)\end{array}$ & $\begin{array}{c}0.29 \\
(0.19)\end{array}$ & $\begin{array}{l}-0.02 \\
(0.02)\end{array}$ & $\begin{array}{l}-0.04 \\
(0.11)\end{array}$ & $\begin{array}{l}-0.03 \\
(0.02)\end{array}$ \\
\hline human & $\begin{array}{c}-0.01 \\
(0.01)\end{array}$ & $\begin{array}{c}0.12 \\
(0.14)\end{array}$ & $\begin{array}{c}0.00 \\
(0.03)\end{array}$ & $\begin{array}{l}-0.04 \\
(0.11)\end{array}$ & $\begin{array}{c}0.00 \\
(0.04)\end{array}$ \\
\hline social & $\begin{array}{c}-0.00 \\
(0.01)\end{array}$ & $\begin{array}{c}0.10 \\
(0.15)\end{array}$ & $\begin{array}{l}-0.01 \\
(0.02)\end{array}$ & $\begin{array}{l}-0.14 \\
(0.09)\end{array}$ & $\begin{array}{l}-0.00 \\
(0.04)\end{array}$ \\
\hline science & & $\begin{array}{c}0.14 \\
(0.17)\end{array}$ & $\begin{array}{l}-0.00 \\
(0.02)\end{array}$ & $\begin{array}{l}-0.08 \\
(0.10)\end{array}$ & $\begin{array}{c}0.02 \\
(0.06)\end{array}$ \\
\hline agvet & $\begin{array}{c}0.04 \\
(0.08)\end{array}$ & $\begin{array}{c}0.00 \\
(0.15)\end{array}$ & & $\begin{array}{l}-0.08 \\
(0.10)\end{array}$ & \\
\hline health & & $\begin{array}{l}-0.09 \\
(0.09)\end{array}$ & & $\begin{array}{c}0.11 \\
(0.19)\end{array}$ & \\
\hline mast & $\begin{array}{c}-0.00 \\
(0.01)\end{array}$ & $\begin{array}{c}-0.13^{* * *} \\
(0.04)\end{array}$ & $\begin{array}{l}-0.02 * \\
(0.01)\end{array}$ & $\begin{array}{l}-0.05 \\
(0.07)\end{array}$ & $\begin{array}{c}-0.03^{* *} \\
(0.01)\end{array}$ \\
\hline first & $\begin{array}{c}0.03 \\
(0.05)\end{array}$ & $\begin{array}{l}-0.04 \\
(0.06)\end{array}$ & $\begin{array}{c}0.01 \\
(0.02)\end{array}$ & $\begin{array}{l}-0.06 \\
(0.06)\end{array}$ & $\begin{array}{l}-0.02 \\
(0.02)\end{array}$ \\
\hline twoone & $\begin{array}{c}-0.00 \\
(0.01)\end{array}$ & $\begin{array}{c}-0.09 * * \\
(0.04)\end{array}$ & $\begin{array}{l}-0.02 \\
(0.01)\end{array}$ & $\begin{array}{l}-0.07 \\
(0.04)\end{array}$ & $\begin{array}{l}-0.00 \\
(0.02)\end{array}$ \\
\hline unemp & $\begin{array}{c}-0.01 \\
(0.01)\end{array}$ & $\begin{array}{l}-0.04 \\
(0.04)\end{array}$ & $\begin{array}{c}0.00 \\
(0.01)\end{array}$ & $\begin{array}{l}-0.07 \\
(0.04)\end{array}$ & $\begin{array}{c}0.01 \\
(0.02)\end{array}$ \\
\hline supervise & $\begin{array}{c}-0.01 \\
(0.01)\end{array}$ & $\begin{array}{l}0.07^{*} \\
(0.04)\end{array}$ & $\begin{array}{c}0.01 \\
(0.01)\end{array}$ & $\begin{array}{l}-0.00 \\
(0.04)\end{array}$ & $\begin{array}{l}0.03^{*} \\
(0.02)\end{array}$ \\
\hline fieldmatchnow & $\begin{array}{c}0.04 \\
(0.03)\end{array}$ & $\begin{array}{l}-0.00 \\
(0.06)\end{array}$ & $\begin{array}{c}0.04 \\
(0.04)\end{array}$ & $\begin{array}{l}0.18^{* *} \\
(0.07)\end{array}$ & $\begin{array}{c}0.05 \\
(0.04)\end{array}$ \\
\hline fieldrelatednow & $\begin{array}{c}0.00 \\
(0.01)\end{array}$ & $\begin{array}{c}0.03 \\
(0.05)\end{array}$ & $\begin{array}{c}0.01 \\
(0.01)\end{array}$ & $\begin{array}{l}0.10^{*} \\
(0.06)\end{array}$ & $\begin{array}{c}0.02 \\
(0.02)\end{array}$ \\
\hline hours & $\begin{array}{c}-0.00 \\
(0.00)\end{array}$ & $\begin{array}{l}-0.00 \\
(0.00)\end{array}$ & $\begin{array}{c}0.00 \\
(0.00)\end{array}$ & $\begin{array}{l}-0.00 \\
(0.00)\end{array}$ & $\begin{array}{c}0.00 \\
(0.00)\end{array}$ \\
\hline coursemp & $\begin{array}{c}-0.01 \\
(0.01)\end{array}$ & $\begin{array}{l}-0.04 \\
(0.04)\end{array}$ & $\begin{array}{l}-0.01 \\
(0.01)\end{array}$ & $\begin{array}{l}-0.03 \\
(0.04)\end{array}$ & $\begin{array}{c}0.02 \\
(0.02)\end{array}$ \\
\hline courseprest & $\begin{array}{c}0.00 \\
(0.01)\end{array}$ & $\begin{array}{c}0.02 \\
(0.04)\end{array}$ & $\begin{array}{l}-0.00 \\
(0.01)\end{array}$ & $\begin{array}{l}-0.04 \\
(0.04)\end{array}$ & $\begin{array}{c}0.00 \\
(0.02)\end{array}$ \\
\hline coursevoc & $\begin{array}{c}-0.01 \\
(0.01)\end{array}$ & $\begin{array}{c}0.03 \\
(0.05)\end{array}$ & $\begin{array}{c}0.01 \\
(0.01)\end{array}$ & $\begin{array}{c}0.02 \\
(0.05)\end{array}$ & $\begin{array}{l}-0.02 \\
(0.01)\end{array}$ \\
\hline rdfirm & $\begin{array}{c}0.01 \\
(0.01)\end{array}$ & $\begin{array}{c}-0.08 * * \\
(0.04)\end{array}$ & $\begin{array}{c}0.00 \\
(0.01)\end{array}$ & $\begin{array}{c}0.11^{* * *} \\
(0.04)\end{array}$ & $\begin{array}{c}0.01 \\
(0.02)\end{array}$ \\
\hline size5099 & $\begin{array}{l}-0.00 \\
(0.01)\end{array}$ & $\begin{array}{c}0.09 \\
(0.09)\end{array}$ & $\begin{array}{c}0.08 \\
(0.07)\end{array}$ & $\begin{array}{c}0.12 \\
(0.10)\end{array}$ & $\begin{array}{l}0.22^{*} \\
(0.13)\end{array}$ \\
\hline size100249 & -0.01 & -0.03 & -0.01 & 0.02 & 0.11 \\
\hline
\end{tabular}




\begin{tabular}{lccccc} 
& $(0.01)$ & $(0.07)$ & $(0.01)$ & $(0.09)$ & $(0.11)$ \\
size250999 & -0.01 & -0.06 & 0.01 & -0.07 & 0.12 \\
size1000 & $(0.01)$ & $(0.05)$ & $(0.03)$ & $(0.06)$ & $(0.09)$ \\
public & $-0.04 *$ & -0.06 & 0.01 & -0.00 & 0.04 \\
& $(0.02)$ & $(0.05)$ & $(0.01)$ & $(0.05)$ & $(0.03)$ \\
numemployers & 0.00 & 0.06 & -0.01 & -0.01 & $0.07 * *$ \\
& $(0.01)$ & $(0.04)$ & $(0.01)$ & $(0.04)$ & $(0.03)$ \\
overskillnow & -0.00 & -0.02 & -0.00 & -0.00 & 0.00 \\
& $(0.00)$ & $(0.01)$ & $(0.00)$ & $(0.01)$ & $(0.00)$ \\
overednow & -0.01 & -0.07 & -0.00 & $-0.09^{*}$ & -0.02 \\
& $(0.01)$ & $(0.05)$ & $(0.01)$ & $(0.05)$ & $(0.02)$ \\
Observations & $0.11^{*}$ & -0.01 & $-0.02^{*}$ & 0.01 & 0.03 \\
Pseudo R-squared & $(0.06)$ & $(0.06)$ & $(0.01)$ & $(0.07)$ & $(0.04)$ \\
\hline
\end{tabular}


Table 6b: Job Characteristic Probits Males

\begin{tabular}{|c|c|c|c|c|c|}
\hline VARIABLES & $\begin{array}{c}(1) \\
\text { Useful }\end{array}$ & $\begin{array}{c}(2) \\
\text { Leisure } \\
\end{array}$ & $\begin{array}{c}(3) \\
\text { Career } \\
\end{array}$ & $\begin{array}{c}(4) \\
\text { Autonomy }\end{array}$ & $\begin{array}{c}(5) \\
\text { Challeng }\end{array}$ \\
\hline labexp & $\begin{array}{l}-0.00 \\
(0.00)\end{array}$ & $\begin{array}{c}0.00 \\
(0.00)\end{array}$ & $\begin{array}{c}0.00 * * \\
(0.00)\end{array}$ & $\begin{array}{c}0.00 \\
(0.00)\end{array}$ & $\begin{array}{l}-0.00 \\
(0.00)\end{array}$ \\
\hline age & $\begin{array}{c}0.00 \\
(0.00)\end{array}$ & $\begin{array}{c}0.00 \\
(0.00)\end{array}$ & $\begin{array}{l}-0.00 \\
(0.00)\end{array}$ & $\begin{array}{c}0.00 \\
(0.00)\end{array}$ & $\begin{array}{l}-0.00 \\
(0.00)\end{array}$ \\
\hline education & $\begin{array}{c}0.12 \\
(0.13)\end{array}$ & $\begin{array}{l}-0.02 \\
(0.08)\end{array}$ & $\begin{array}{c}0.21 \\
(0.21)\end{array}$ & $\begin{array}{l}-0.08 \\
(0.06)\end{array}$ & $\begin{array}{c}-0.11^{* *} \\
(0.05)\end{array}$ \\
\hline human & $\begin{array}{c}0.05 \\
(0.09)\end{array}$ & $\begin{array}{l}-0.09 \\
(0.08)\end{array}$ & $\begin{array}{c}0.27 \\
(0.18)\end{array}$ & $\begin{array}{l}-0.07 \\
(0.08)\end{array}$ & $\begin{array}{l}-0.10 \\
(0.08)\end{array}$ \\
\hline social & $\begin{array}{c}0.07 \\
(0.11)\end{array}$ & $\begin{array}{l}-0.07 \\
(0.07)\end{array}$ & $\begin{array}{c}0.15 \\
(0.18)\end{array}$ & $\begin{array}{l}-0.10 \\
(0.06)\end{array}$ & $\begin{array}{l}-0.11 * \\
(0.06)\end{array}$ \\
\hline science & $\begin{array}{c}0.10 \\
(0.14)\end{array}$ & $\begin{array}{l}-0.05 \\
(0.08)\end{array}$ & $\begin{array}{c}0.18 \\
(0.21)\end{array}$ & $\begin{array}{c}-0.12 * * * \\
(0.04)\end{array}$ & $\begin{array}{l}-0.09 * \\
(0.05)\end{array}$ \\
\hline agvet & $\begin{array}{c}0.04 \\
(0.15)\end{array}$ & $\begin{array}{l}-0.03 \\
(0.09)\end{array}$ & $\begin{array}{c}0.11 \\
(0.23)\end{array}$ & $\begin{array}{l}-0.04 \\
(0.08)\end{array}$ & \\
\hline health & $\begin{array}{c}0.34 \\
(0.25)\end{array}$ & $\begin{array}{c}-0.11 * * * \\
(0.03)\end{array}$ & $\begin{array}{c}0.05 \\
(0.21)\end{array}$ & $\begin{array}{l}-0.02 \\
(0.10)\end{array}$ & $\begin{array}{l}-0.03 \\
(0.10)\end{array}$ \\
\hline mast & $\begin{array}{l}-0.04 \\
(0.04)\end{array}$ & $\begin{array}{l}-0.07 \\
(0.05)\end{array}$ & $\begin{array}{l}-0.07 \\
(0.05)\end{array}$ & $\begin{array}{c}0.07 \\
(0.08)\end{array}$ & $\begin{array}{l}-0.02 \\
(0.06)\end{array}$ \\
\hline first & $\begin{array}{c}-0.06^{* *} \\
(0.03)\end{array}$ & $\begin{array}{c}0.02 \\
(0.07)\end{array}$ & $\begin{array}{c}-0.10^{* *} \\
(0.04)\end{array}$ & $\begin{array}{l}0.18^{*} \\
(0.10)\end{array}$ & $\begin{array}{c}0.03 \\
(0.07)\end{array}$ \\
\hline twoone & $\begin{array}{c}0.01 \\
(0.03)\end{array}$ & $\begin{array}{c}0.02 \\
(0.04)\end{array}$ & $\begin{array}{c}-0.10 * * * \\
(0.04)\end{array}$ & $\begin{array}{c}0.00 \\
(0.04)\end{array}$ & $\begin{array}{l}-0.01 \\
(0.04)\end{array}$ \\
\hline unemp & $\begin{array}{l}-0.03 \\
(0.03)\end{array}$ & $\begin{array}{c}0.02 \\
(0.04)\end{array}$ & $\begin{array}{l}-0.02 \\
(0.04)\end{array}$ & $\begin{array}{c}0.03 \\
(0.04)\end{array}$ & $\begin{array}{l}-0.02 \\
(0.04)\end{array}$ \\
\hline supervise & $\begin{array}{c}0.03 \\
(0.03)\end{array}$ & $\begin{array}{c}0.01 \\
(0.04)\end{array}$ & $\begin{array}{c}0.04 \\
(0.04)\end{array}$ & $\begin{array}{c}0.08 * * \\
(0.04)\end{array}$ & $\begin{array}{l}0.06^{*} \\
(0.04)\end{array}$ \\
\hline fieldmatchnow & $\begin{array}{l}-0.05 \\
(0.03)\end{array}$ & $\begin{array}{c}0.08 \\
(0.06)\end{array}$ & $\begin{array}{l}0.14^{*} \\
(0.07)\end{array}$ & $\begin{array}{c}0.02 \\
(0.05)\end{array}$ & $\begin{array}{c}0.03 \\
(0.06)\end{array}$ \\
\hline fieldrelatednow & $\begin{array}{l}-0.03 \\
(0.03)\end{array}$ & $\begin{array}{c}0.05 \\
(0.05)\end{array}$ & $\begin{array}{c}0.09 \\
(0.05)\end{array}$ & $\begin{array}{c}0.05 \\
(0.04)\end{array}$ & $\begin{array}{l}-0.02 \\
(0.04)\end{array}$ \\
\hline hours & $\begin{array}{l}-0.00 \\
(0.00)\end{array}$ & $\begin{array}{c}-0.00 * * \\
(0.00)\end{array}$ & $\begin{array}{c}0.00 \\
(0.00)\end{array}$ & $\begin{array}{c}-0.00^{* *} \\
(0.00)\end{array}$ & $\begin{array}{l}-0.00 \\
(0.00)\end{array}$ \\
\hline coursemp & $\begin{array}{l}-0.01 \\
(0.03)\end{array}$ & $\begin{array}{l}-0.02 \\
(0.04)\end{array}$ & $\begin{array}{l}-0.01 \\
(0.04)\end{array}$ & $\begin{array}{l}-0.06^{*} \\
(0.03)\end{array}$ & $\begin{array}{c}0.01 \\
(0.04)\end{array}$ \\
\hline courseprest & $\begin{array}{c}0.03 \\
(0.03)\end{array}$ & $\begin{array}{l}-0.01 \\
(0.04)\end{array}$ & $\begin{array}{c}0.02 \\
(0.04)\end{array}$ & $\begin{array}{l}-0.01 \\
(0.04)\end{array}$ & $\begin{array}{c}0.02 \\
(0.04)\end{array}$ \\
\hline coursevoc & $\begin{array}{c}-0.07 * * * \\
(0.03)\end{array}$ & $\begin{array}{l}-0.02 \\
(0.04)\end{array}$ & $\begin{array}{c}0.01 \\
(0.04)\end{array}$ & $\begin{array}{c}0.10^{* * *} \\
(0.05)\end{array}$ & $\begin{array}{l}-0.05 \\
(0.04)\end{array}$ \\
\hline rdfirm & $\begin{array}{c}0.01 \\
(0.03)\end{array}$ & $\begin{array}{l}0.06^{*} \\
(0.04)\end{array}$ & $\begin{array}{c}0.03 \\
(0.04)\end{array}$ & $\begin{array}{c}0.03 \\
(0.03)\end{array}$ & $\begin{array}{c}0.15^{* * *} \\
(0.04)\end{array}$ \\
\hline size5099 & $\begin{array}{c}0.07 \\
(0.07)\end{array}$ & $\begin{array}{l}-0.02 \\
(0.07)\end{array}$ & $\begin{array}{c}0.15 \\
(0.10)\end{array}$ & $\begin{array}{c}0.05 \\
(0.08)\end{array}$ & $\begin{array}{c}0.16 \\
(0.10)\end{array}$ \\
\hline size100249 & $\begin{array}{c}0.01 \\
(0.05)\end{array}$ & $\begin{array}{c}0.16 \\
(0.11)\end{array}$ & $\begin{array}{c}0.11 \\
(0.10)\end{array}$ & $\begin{array}{l}-0.03 \\
(0.06)\end{array}$ & $\begin{array}{l}-0.05 \\
(0.06)\end{array}$ \\
\hline
\end{tabular}




\begin{tabular}{lccccc} 
size250999 & $-0.08^{* * *}$ & -0.05 & -0.08 & -0.02 & -0.06 \\
size1000 & $(0.02)$ & $(0.05)$ & $(0.05)$ & $(0.06)$ & $(0.05)$ \\
\multirow{3}{*}{ public } & $-0.12^{* * *}$ & $0.07 *$ & -0.01 & -0.02 & -0.00 \\
& $(0.04)$ & $(0.04)$ & $(0.05)$ & $(0.04)$ & $(0.04)$ \\
numemployers & $0.18^{* * *}$ & $0.09^{* *}$ & 0.01 & 0.03 & 0.06 \\
& $(0.04)$ & $(0.04)$ & $(0.04)$ & $(0.04)$ & $(0.04)$ \\
overskillnow & 0.00 & -0.00 & 0.01 & -0.00 & -0.00 \\
& $(0.01)$ & $(0.01)$ & $(0.01)$ & $(0.01)$ & $(0.01)$ \\
overednow & $-0.08^{* * *}$ & -0.03 & $-0.08^{*}$ & 0.01 & -0.04 \\
& $(0.02)$ & $(0.05)$ & $(0.05)$ & $(0.05)$ & $(0.05)$ \\
& 0.05 & 0.09 & 0.04 & 0.04 & 0.01 \\
Observations & $(0.06)$ & $(0.07)$ & $(0.07)$ & $(0.06)$ & $(0.06)$ \\
Pseudo R-squared & & & & & \\
\hline
\end{tabular}


Table 7a: Job Characteristic Probits - Females

\begin{tabular}{|c|c|c|c|c|c|}
\hline VARIABLES & $\begin{array}{c}\text { (1) } \\
\text { Family }\end{array}$ & $\begin{array}{c}(2) \\
\text { Security }\end{array}$ & $\begin{array}{c}(3) \\
\text { Earnings }\end{array}$ & $\begin{array}{c}(4) \\
\text { Learning }\end{array}$ & $\begin{array}{c}5) \\
\text { Status } \\
\end{array}$ \\
\hline labexp & $\begin{array}{l}-0.00 \\
(0.00)\end{array}$ & $\begin{array}{c}0.00 \\
(0.00)\end{array}$ & $\begin{array}{l}-0.00^{*} \\
(0.00)\end{array}$ & $\begin{array}{l}-0.00 \\
(0.00)\end{array}$ & $\begin{array}{l}-0.00 \\
(0.00)\end{array}$ \\
\hline age & $\begin{array}{c}0.00 \\
(0.00)\end{array}$ & $\begin{array}{c}0.00 \\
(0.00)\end{array}$ & $\begin{array}{c}0.00 \\
(0.00)\end{array}$ & $\begin{array}{l}0.01 * * \\
(0.00)\end{array}$ & $\begin{array}{c}0.00 \\
(0.00)\end{array}$ \\
\hline education & $\begin{array}{l}-0.02 \\
(0.04)\end{array}$ & $\begin{array}{c}0.03 \\
(0.07)\end{array}$ & $\begin{array}{c}0.01 \\
(0.03)\end{array}$ & $\begin{array}{l}-0.08 \\
(0.06)\end{array}$ & $\begin{array}{c}0.01 \\
(0.03)\end{array}$ \\
\hline human & $\begin{array}{c}0.03 \\
(0.05)\end{array}$ & $\begin{array}{l}-0.02 \\
(0.07)\end{array}$ & $\begin{array}{c}0.03 \\
(0.03)\end{array}$ & $\begin{array}{l}-0.06 \\
(0.06)\end{array}$ & $\begin{array}{c}0.05 \\
(0.04)\end{array}$ \\
\hline social & $\begin{array}{l}-0.02 \\
(0.04)\end{array}$ & $\begin{array}{l}-0.05 \\
(0.07)\end{array}$ & $\begin{array}{l}-0.03 \\
(0.02)\end{array}$ & $\begin{array}{l}-0.00 \\
(0.07)\end{array}$ & $\begin{array}{c}0.01 \\
(0.04)\end{array}$ \\
\hline science & $\begin{array}{c}-0.08^{* *} \\
(0.04)\end{array}$ & $\begin{array}{l}-0.12 \\
(0.16)\end{array}$ & $\begin{array}{c}0.08 \\
(0.16)\end{array}$ & $\begin{array}{c}0.23 \\
(0.23)\end{array}$ & \\
\hline agvet & & $\begin{array}{l}-0.05 \\
(0.17)\end{array}$ & & & \\
\hline health & $\begin{array}{l}-0.01 \\
(0.05)\end{array}$ & $\begin{array}{c}0.10 \\
(0.10)\end{array}$ & & $\begin{array}{c}0.03 \\
(0.09)\end{array}$ & $\begin{array}{c}0.03 \\
(0.05)\end{array}$ \\
\hline mast & $\begin{array}{c}0.06 \\
(0.07)\end{array}$ & $\begin{array}{l}-0.08 \\
(0.07)\end{array}$ & & $\begin{array}{c}0.07 \\
(0.08)\end{array}$ & $\begin{array}{l}-0.02 \\
(0.02)\end{array}$ \\
\hline first & $\begin{array}{c}0.07 \\
(0.06)\end{array}$ & $\begin{array}{l}-0.09 \\
(0.06)\end{array}$ & $\begin{array}{l}-0.01 \\
(0.03)\end{array}$ & $\begin{array}{c}0.09 \\
(0.07)\end{array}$ & $\begin{array}{c}-0.03 * * * \\
(0.01)\end{array}$ \\
\hline twoone & $\begin{array}{c}0.01 \\
(0.03)\end{array}$ & $\begin{array}{l}-0.06 \\
(0.04)\end{array}$ & $\begin{array}{l}-0.02 \\
(0.02)\end{array}$ & $\begin{array}{l}-0.06 \\
(0.04)\end{array}$ & $\begin{array}{l}-0.02 \\
(0.02)\end{array}$ \\
\hline unemp & $\begin{array}{c}0.01 \\
(0.03)\end{array}$ & $\begin{array}{l}-0.06 \\
(0.04)\end{array}$ & $\begin{array}{l}-0.02 \\
(0.02)\end{array}$ & $\begin{array}{l}-0.03 \\
(0.04)\end{array}$ & $\begin{array}{c}0.01 \\
(0.02)\end{array}$ \\
\hline supervise & $\begin{array}{l}-0.03 \\
(0.02)\end{array}$ & $\begin{array}{c}0.02 \\
(0.04)\end{array}$ & $\begin{array}{l}-0.01 \\
(0.02)\end{array}$ & $\begin{array}{l}-0.03 \\
(0.04)\end{array}$ & $\begin{array}{c}-0.03 * * \\
(0.01)\end{array}$ \\
\hline fieldmatchnow & $\begin{array}{l}-0.01 \\
(0.04)\end{array}$ & $\begin{array}{c}0.09 \\
(0.06)\end{array}$ & $\begin{array}{c}0.03 \\
(0.03)\end{array}$ & $\begin{array}{c}0.02 \\
(0.06)\end{array}$ & $\begin{array}{l}-0.01 \\
(0.02)\end{array}$ \\
\hline fieldrelatednow & $\begin{array}{c}0.02 \\
(0.03)\end{array}$ & $\begin{array}{l}-0.01 \\
(0.05)\end{array}$ & $\begin{array}{l}-0.02 \\
(0.02)\end{array}$ & $\begin{array}{l}-0.04 \\
(0.05)\end{array}$ & $\begin{array}{l}-0.01 \\
(0.02)\end{array}$ \\
\hline hours & $\begin{array}{c}-0.00 * * \\
(0.00)\end{array}$ & $\begin{array}{c}0.00 \\
(0.00)\end{array}$ & $\begin{array}{c}0.00 * * * \\
(0.00)\end{array}$ & $\begin{array}{l}0.01 * * \\
(0.00)\end{array}$ & $\begin{array}{l}0.00 * * \\
(0.00)\end{array}$ \\
\hline coursemp & $\begin{array}{l}0.06^{*} \\
(0.03)\end{array}$ & $\begin{array}{l}-0.02 \\
(0.04)\end{array}$ & $\begin{array}{c}0.06 * * \\
(0.03)\end{array}$ & $\begin{array}{c}0.02 \\
(0.04)\end{array}$ & $\begin{array}{c}0.02 \\
(0.02)\end{array}$ \\
\hline courseprest & $\begin{array}{c}0.03 \\
(0.02)\end{array}$ & $\begin{array}{c}0.03 \\
(0.04)\end{array}$ & $\begin{array}{c}0.02 \\
(0.02)\end{array}$ & $\begin{array}{c}0.05 \\
(0.04)\end{array}$ & $\begin{array}{c}0.01 \\
(0.01)\end{array}$ \\
\hline coursevoc & $\begin{array}{c}0.01 \\
(0.03)\end{array}$ & $\begin{array}{c}0.05 \\
(0.05)\end{array}$ & $\begin{array}{l}-0.01 \\
(0.02)\end{array}$ & $\begin{array}{l}-0.06 \\
(0.04)\end{array}$ & $\begin{array}{c}0.02 \\
(0.02)\end{array}$ \\
\hline rdfirm & $\begin{array}{l}-0.03 \\
(0.02)\end{array}$ & $\begin{array}{c}0.04 \\
(0.04)\end{array}$ & $\begin{array}{c}0.01 \\
(0.02)\end{array}$ & $\begin{array}{l}0.09 * * \\
(0.04)\end{array}$ & $\begin{array}{l}-0.01 \\
(0.01)\end{array}$ \\
\hline size5099 & $\begin{array}{c}0.01 \\
(0.04)\end{array}$ & $\begin{array}{c}0.05 \\
(0.07)\end{array}$ & $\begin{array}{l}-0.01 \\
(0.03)\end{array}$ & $\begin{array}{c}0.00 \\
(0.07)\end{array}$ & $\begin{array}{c}0.03 \\
(0.03)\end{array}$ \\
\hline size100249 & $\begin{array}{l}-0.03 \\
(0.03)\end{array}$ & $\begin{array}{c}0.06 \\
(0.08)\end{array}$ & $\begin{array}{c}-0.03^{* *} \\
(0.02)\end{array}$ & $\begin{array}{l}-0.09 \\
(0.06)\end{array}$ & $\begin{array}{l}-0.00 \\
(0.02)\end{array}$ \\
\hline size250999 & $-0.07 * * *$ & -0.02 & 0.00 & -0.02 & $-0.03^{* *}$ \\
\hline
\end{tabular}




\begin{tabular}{lccccc} 
& $(0.02)$ & $(0.06)$ & $(0.03)$ & $(0.06)$ & $(0.01)$ \\
size1000 & $-0.05^{*}$ & $-0.09^{* *}$ & -0.03 & $-0.09^{* *}$ & $-0.05^{* * *}$ \\
public & $(0.03)$ & $(0.05)$ & $(0.02)$ & $(0.04)$ & $(0.02)$ \\
& $0.07^{* * *}$ & $0.19^{* * *}$ & 0.01 & $0.13^{* * *}$ & 0.02 \\
numemployers & $(0.02)$ & $(0.04)$ & $(0.02)$ & $(0.04)$ & $(0.01)$ \\
& $0.01^{*}$ & $-0.03^{* *}$ & -0.01 & -0.01 & $-0.01^{* *}$ \\
overskillnow & $(0.00)$ & $(0.01)$ & $(0.01)$ & $(0.01)$ & $(0.01)$ \\
& 0.04 & 0.02 & -0.00 & -0.06 & \\
overednow & $(0.05)$ & $(0.07)$ & $(0.04)$ & $(0.06)$ & \\
& 0.01 & $0.17^{* *}$ & -0.02 & -0.09 & 0.02 \\
Observations & $(0.05)$ & $(0.08)$ & $(0.03)$ & $(0.06)$ & $(0.04)$ \\
Pseudo R-squared & & & & & \\
\hline
\end{tabular}


Table 7b: Job Characteristic Probits Females

\begin{tabular}{|c|c|c|c|c|c|}
\hline VARIABLES & $\begin{array}{c}\text { (1) } \\
\text { Useful }\end{array}$ & $\begin{array}{c}(2) \\
\text { Leisure }\end{array}$ & $\begin{array}{c}(3) \\
\text { Career }\end{array}$ & $\begin{array}{c}\text { (4) } \\
\text { Autonom }\end{array}$ & $\begin{array}{c}\text { (5) } \\
\text { Challengin } \\
\end{array}$ \\
\hline labexp & $\begin{array}{c}-0.00 * * \\
(0.00)\end{array}$ & $\begin{array}{l}-0.00 \\
(0.00)\end{array}$ & $\begin{array}{l}-0.00 \\
(0.00)\end{array}$ & $\begin{array}{c}-0.00 * * \\
(0.00)\end{array}$ & $\begin{array}{c}-0.00 * * \\
(0.00)\end{array}$ \\
\hline age & $\begin{array}{l}0.00 * \\
(0.00)\end{array}$ & $\begin{array}{l}-0.00 \\
(0.00)\end{array}$ & $\begin{array}{l}-0.00 \\
(0.00)\end{array}$ & $\begin{array}{c}0.01^{* * *} \\
(0.00)\end{array}$ & $\begin{array}{c}0.00 \\
(0.00)\end{array}$ \\
\hline education & $\begin{array}{l}-0.05 \\
(0.06)\end{array}$ & $\begin{array}{c}0.05 \\
(0.07)\end{array}$ & $\begin{array}{l}-0.00 \\
(0.05)\end{array}$ & $\begin{array}{l}-0.04 \\
(0.05)\end{array}$ & $\begin{array}{c}0.03 \\
(0.07)\end{array}$ \\
\hline human & $\begin{array}{l}-0.06 \\
(0.06)\end{array}$ & $\begin{array}{c}0.11 \\
(0.07)\end{array}$ & $\begin{array}{l}-0.00 \\
(0.05)\end{array}$ & $\begin{array}{c}0.00 \\
(0.06)\end{array}$ & $\begin{array}{c}0.03 \\
(0.07)\end{array}$ \\
\hline social & $\begin{array}{l}-0.09 \\
(0.06)\end{array}$ & $\begin{array}{c}0.08 \\
(0.08)\end{array}$ & $\begin{array}{l}-0.02 \\
(0.05)\end{array}$ & $\begin{array}{c}0.01 \\
(0.07)\end{array}$ & $\begin{array}{c}0.02 \\
(0.07)\end{array}$ \\
\hline science & $\begin{array}{l}-0.06 \\
(0.15)\end{array}$ & & & $\begin{array}{c}0.04 \\
(0.17)\end{array}$ & $\begin{array}{c}0.19 \\
(0.23)\end{array}$ \\
\hline health & $\begin{array}{l}-0.05 \\
(0.07)\end{array}$ & $\begin{array}{l}-0.02 \\
(0.08)\end{array}$ & $\begin{array}{l}-0.05 \\
(0.05)\end{array}$ & $\begin{array}{c}0.01 \\
(0.08)\end{array}$ & $\begin{array}{c}0.04 \\
(0.09)\end{array}$ \\
\hline mast & $\begin{array}{c}0.02 \\
(0.08)\end{array}$ & $\begin{array}{l}-0.03 \\
(0.06)\end{array}$ & $\begin{array}{c}-0.08^{* *} \\
(0.04)\end{array}$ & $\begin{array}{l}-0.01 \\
(0.06)\end{array}$ & $\begin{array}{l}-0.06 \\
(0.06)\end{array}$ \\
\hline first & $\begin{array}{c}0.13 \\
(0.08)\end{array}$ & $\begin{array}{c}0.03 \\
(0.06)\end{array}$ & $\begin{array}{c}0.03 \\
(0.06)\end{array}$ & $\begin{array}{c}0.03 \\
(0.06)\end{array}$ & $\begin{array}{c}0.05 \\
(0.07)\end{array}$ \\
\hline twoone & $\begin{array}{c}0.04 \\
(0.04)\end{array}$ & $\begin{array}{l}-0.05 \\
(0.04)\end{array}$ & $\begin{array}{l}-0.03 \\
(0.03)\end{array}$ & $\begin{array}{l}-0.03 \\
(0.03)\end{array}$ & $\begin{array}{l}-0.04 \\
(0.04)\end{array}$ \\
\hline unemp & $\begin{array}{c}0.02 \\
(0.04)\end{array}$ & $\begin{array}{c}0.05 \\
(0.04)\end{array}$ & $\begin{array}{c}-0.08 * * * \\
(0.03)\end{array}$ & $\begin{array}{l}-0.01 \\
(0.03)\end{array}$ & $\begin{array}{c}-0.07^{* *} \\
(0.03)\end{array}$ \\
\hline supervise & $\begin{array}{c}0.00 \\
(0.03)\end{array}$ & $\begin{array}{c}-0.07 * * \\
(0.03)\end{array}$ & $\begin{array}{l}-0.02 \\
(0.03)\end{array}$ & $\begin{array}{c}0.01 \\
(0.03)\end{array}$ & $\begin{array}{l}-0.00 \\
(0.03)\end{array}$ \\
\hline fieldmatchnow & $\begin{array}{c}0.01 \\
(0.05)\end{array}$ & $\begin{array}{c}0.01 \\
(0.05)\end{array}$ & $\begin{array}{l}0.08 * \\
(0.05)\end{array}$ & $\begin{array}{l}-0.01 \\
(0.05)\end{array}$ & $\begin{array}{c}0.06 \\
(0.06)\end{array}$ \\
\hline fieldrelatednow & $\begin{array}{c}-0.09 * * \\
(0.04)\end{array}$ & $\begin{array}{l}-0.04 \\
(0.04)\end{array}$ & $\begin{array}{c}0.00 \\
(0.04)\end{array}$ & $\begin{array}{l}-0.05 \\
(0.04)\end{array}$ & $\begin{array}{l}-0.02 \\
(0.04)\end{array}$ \\
\hline hours & $\begin{array}{l}-0.00 \\
(0.00)\end{array}$ & $\begin{array}{l}-0.00 * \\
(0.00)\end{array}$ & $\begin{array}{c}0.00 * * \\
(0.00)\end{array}$ & $\begin{array}{c}0.00 \\
(0.00)\end{array}$ & $\begin{array}{c}0.01 * * \\
(0.00)\end{array}$ \\
\hline coursemp & $\begin{array}{l}-0.06 \\
(0.04)\end{array}$ & $\begin{array}{c}0.00 \\
(0.04)\end{array}$ & $\begin{array}{c}0.11^{* * *} \\
(0.04)\end{array}$ & $\begin{array}{c}0.14^{* * *} \\
(0.04)\end{array}$ & $\begin{array}{c}0.06 \\
(0.04)\end{array}$ \\
\hline courseprest & $\begin{array}{l}0.07 * \\
(0.03)\end{array}$ & $\begin{array}{c}0.02 \\
(0.03)\end{array}$ & $\begin{array}{c}0.01 \\
(0.03)\end{array}$ & $\begin{array}{l}-0.05^{*} \\
(0.03)\end{array}$ & $\begin{array}{c}0.04 \\
(0.03)\end{array}$ \\
\hline coursevoc & $\begin{array}{c}0.00 \\
(0.04)\end{array}$ & $\begin{array}{c}0.00 \\
(0.04)\end{array}$ & $\begin{array}{l}-0.04 \\
(0.03)\end{array}$ & $\begin{array}{l}-0.05 \\
(0.03)\end{array}$ & $\begin{array}{l}-0.07^{*} \\
(0.04)\end{array}$ \\
\hline rdfirm & $\begin{array}{c}0.02 \\
(0.03)\end{array}$ & $\begin{array}{l}-0.06^{*} \\
(0.03)\end{array}$ & $\begin{array}{c}0.04 \\
(0.03)\end{array}$ & $\begin{array}{c}0.02 \\
(0.03)\end{array}$ & $\begin{array}{l}0.06^{*} \\
(0.03)\end{array}$ \\
\hline size5099 & $\begin{array}{c}0.05 \\
(0.07)\end{array}$ & $\begin{array}{c}0.08 \\
(0.07)\end{array}$ & $\begin{array}{c}0.00 \\
(0.05)\end{array}$ & $\begin{array}{c}0.07 \\
(0.07)\end{array}$ & $\begin{array}{c}0.04 \\
(0.07)\end{array}$ \\
\hline size100249 & $\begin{array}{l}-0.00 \\
(0.06)\end{array}$ & $\begin{array}{c}0.08 \\
(0.07)\end{array}$ & $\begin{array}{c}-0.07 * * \\
(0.04)\end{array}$ & $\begin{array}{c}0.04 \\
(0.06)\end{array}$ & $\begin{array}{l}-0.03 \\
(0.06)\end{array}$ \\
\hline size250999 & $\begin{array}{l}-0.03 \\
(0.05)\end{array}$ & $\begin{array}{c}0.01 \\
(0.05)\end{array}$ & $\begin{array}{l}-0.03 \\
(0.04)\end{array}$ & $\begin{array}{l}-0.02 \\
(0.05)\end{array}$ & $\begin{array}{l}-0.06 \\
(0.05)\end{array}$ \\
\hline size1000 & $-0.10^{* *}$ & 0.02 & -0.03 & -0.02 & -0.05 \\
\hline
\end{tabular}




\begin{tabular}{lccccc} 
& $(0.04)$ & $(0.04)$ & $(0.03)$ & $(0.04)$ & $(0.04)$ \\
public & $0.23^{* * *}$ & 0.04 & $0.09 * * *$ & 0.03 & $0.09^{* * *}$ \\
numemployers & $(0.03)$ & $(0.03)$ & $(0.03)$ & $(0.03)$ & $(0.03)$ \\
& -0.00 & 0.00 & $0.02^{*}$ & 0.00 & 0.01 \\
overskillnow & $(0.01)$ & $(0.01)$ & $(0.01)$ & $(0.00)$ & $(0.01)$ \\
& 0.04 & 0.02 & 0.04 & 0.05 & $0.13^{*}$ \\
overednow & $(0.07)$ & $(0.06)$ & $(0.06)$ & $(0.06)$ & $(0.08)$ \\
& -0.01 & 0.02 & $-0.07^{*}$ & $-0.08^{*}$ & $-0.13^{* * *}$ \\
Observations & $(0.06)$ & $(0.06)$ & $(0.04)$ & $(0.04)$ & $(0.04)$ \\
Pseudo R-squared & & & & & \\
\hline
\end{tabular}


Table 8: Job Satisfaction equation with competency based overskilling controls

\begin{tabular}{|c|c|c|c|c|c|}
\hline VARIABLES & $\begin{array}{c}(1) \\
\text { Model }\end{array}$ & $\begin{array}{c}(2) \\
\text { Model }\end{array}$ & $\begin{array}{c}(3) \\
\text { Model }\end{array}$ & $\begin{array}{c}\text { (4) } \\
\text { Males }\end{array}$ & $\begin{array}{c}\text { (5) } \\
\text { Females }\end{array}$ \\
\hline male & $\begin{array}{l}0.07 * \\
(0.03)\end{array}$ & $\begin{array}{l}0.06^{*} \\
(0.03)\end{array}$ & $\begin{array}{c}0.08 * * \\
(0.04)\end{array}$ & & \\
\hline labexp & $\begin{array}{l}-0.00 \\
(0.00)\end{array}$ & $\begin{array}{l}-0.00 \\
(0.00)\end{array}$ & $\begin{array}{l}-0.00 \\
(0.00)\end{array}$ & $\begin{array}{c}-0.00 \\
(0.00)\end{array}$ & $\begin{array}{l}-0.00 \\
(0.00)\end{array}$ \\
\hline age & $\begin{array}{l}-0.00 \\
(0.00)\end{array}$ & $\begin{array}{l}-0.00 \\
(0.00)\end{array}$ & $\begin{array}{l}-0.00 \\
(0.00)\end{array}$ & $\begin{array}{c}0.01 \\
(0.01)\end{array}$ & $\begin{array}{l}-0.00 \\
(0.00)\end{array}$ \\
\hline education & $\begin{array}{c}0.10 \\
(0.07)\end{array}$ & $\begin{array}{c}0.10 \\
(0.07)\end{array}$ & $\begin{array}{l}0.12^{*} \\
(0.07)\end{array}$ & $\begin{array}{c}0.18 \\
(0.14)\end{array}$ & $\begin{array}{c}0.09 \\
(0.08)\end{array}$ \\
\hline human & $\begin{array}{l}0.12^{*} \\
(0.06)\end{array}$ & $\begin{array}{l}0.12^{*} \\
(0.07)\end{array}$ & $\begin{array}{c}0.14^{* *} \\
(0.07)\end{array}$ & $\begin{array}{c}0.13 \\
(0.15)\end{array}$ & $\begin{array}{c}0.12 \\
(0.08)\end{array}$ \\
\hline social & $\begin{array}{c}0.06 \\
(0.07)\end{array}$ & $\begin{array}{c}0.06 \\
(0.07)\end{array}$ & $\begin{array}{c}0.08 \\
(0.07)\end{array}$ & $\begin{array}{c}0.10 \\
(0.15)\end{array}$ & $\begin{array}{c}0.07 \\
(0.09)\end{array}$ \\
\hline science & $\begin{array}{c}0.04 \\
(0.09)\end{array}$ & $\begin{array}{c}0.05 \\
(0.09)\end{array}$ & $\begin{array}{c}0.06 \\
(0.09)\end{array}$ & $\begin{array}{c}0.01 \\
(0.17)\end{array}$ & $\begin{array}{c}0.35 * * * \\
(0.10)\end{array}$ \\
\hline agvet & $\begin{array}{c}0.05 \\
(0.12)\end{array}$ & $\begin{array}{c}0.00 \\
(0.13)\end{array}$ & $\begin{array}{c}0.02 \\
(0.13)\end{array}$ & $\begin{array}{l}-0.01 \\
(0.21)\end{array}$ & $\begin{array}{l}-0.08 \\
(0.21)\end{array}$ \\
\hline health & $\begin{array}{l}0.16^{* *} \\
(0.08)\end{array}$ & $\begin{array}{c}0.17 * * \\
(0.08)\end{array}$ & $\begin{array}{c}0.17 * * \\
(0.08)\end{array}$ & $\begin{array}{l}-0.17 \\
(0.23)\end{array}$ & $\begin{array}{c}0.26 * * * \\
(0.08)\end{array}$ \\
\hline mast & $\begin{array}{c}0.01 \\
(0.07)\end{array}$ & $\begin{array}{l}-0.00 \\
(0.07)\end{array}$ & $\begin{array}{l}-0.01 \\
(0.07)\end{array}$ & $\begin{array}{l}-0.03 \\
(0.11)\end{array}$ & $\begin{array}{c}0.01 \\
(0.10)\end{array}$ \\
\hline first & $\begin{array}{c}0.06 \\
(0.06)\end{array}$ & $\begin{array}{c}0.06 \\
(0.06)\end{array}$ & $\begin{array}{c}0.05 \\
(0.06)\end{array}$ & $\begin{array}{l}-0.04 \\
(0.12)\end{array}$ & $\begin{array}{c}0.09 \\
(0.08)\end{array}$ \\
\hline twoone & $\begin{array}{c}0.04 \\
(0.04)\end{array}$ & $\begin{array}{c}0.05 \\
(0.04)\end{array}$ & $\begin{array}{c}0.04 \\
(0.04)\end{array}$ & $\begin{array}{c}-0.02 \\
(0.06)\end{array}$ & $\begin{array}{c}0.07 \\
(0.05)\end{array}$ \\
\hline unemp & $\begin{array}{c}0.03 \\
(0.04)\end{array}$ & $\begin{array}{c}0.02 \\
(0.03)\end{array}$ & $\begin{array}{c}0.04 \\
(0.04)\end{array}$ & $\begin{array}{l}-0.03 \\
(0.06)\end{array}$ & $\begin{array}{l}0.08^{*} \\
(0.05)\end{array}$ \\
\hline supervise & $\begin{array}{l}-0.00 \\
(0.03)\end{array}$ & $\begin{array}{l}-0.00 \\
(0.03)\end{array}$ & $\begin{array}{l}-0.01 \\
(0.03)\end{array}$ & $\begin{array}{l}-0.05 \\
(0.06)\end{array}$ & $\begin{array}{l}-0.00 \\
(0.04)\end{array}$ \\
\hline fieldmatchnow & $\begin{array}{l}-0.09 \\
(0.06)\end{array}$ & $\begin{array}{l}-0.04 \\
(0.05)\end{array}$ & $\begin{array}{l}-0.11^{*} \\
(0.06)\end{array}$ & $\begin{array}{l}-0.10 \\
(0.10)\end{array}$ & $\begin{array}{l}-0.11 \\
(0.08)\end{array}$ \\
\hline fieldrelatednow & $\begin{array}{l}0.07^{*} \\
(0.04)\end{array}$ & $\begin{array}{c}0.12 * * * \\
(0.04)\end{array}$ & $\begin{array}{c}0.06 \\
(0.05)\end{array}$ & $\begin{array}{l}0.14 * \\
(0.08)\end{array}$ & $\begin{array}{c}0.02 \\
(0.06)\end{array}$ \\
\hline fieldmatchjob1 & $\begin{array}{c}0.03 \\
(0.06)\end{array}$ & $\begin{array}{l}-0.02 \\
(0.06)\end{array}$ & $\begin{array}{c}0.03 \\
(0.06)\end{array}$ & $\begin{array}{c}0.06 \\
(0.10)\end{array}$ & $\begin{array}{c}0.05 \\
(0.08)\end{array}$ \\
\hline fieldrelatedjob1 & $\begin{array}{c}0.04 \\
(0.05)\end{array}$ & $\begin{array}{c}0.01 \\
(0.04)\end{array}$ & $\begin{array}{c}0.04 \\
(0.05)\end{array}$ & $\begin{array}{l}-0.03 \\
(0.09)\end{array}$ & $\begin{array}{c}0.07 \\
(0.06)\end{array}$ \\
\hline hours & $\begin{array}{l}0.00 * * \\
(0.00)\end{array}$ & $\begin{array}{l}0.00 * * \\
(0.00)\end{array}$ & $\begin{array}{l}0.00 * * \\
(0.00)\end{array}$ & $\begin{array}{c}0.01 * * * \\
(0.00)\end{array}$ & $\begin{array}{l}-0.00 \\
(0.00)\end{array}$ \\
\hline coursemp & $\begin{array}{l}-0.03 \\
(0.04)\end{array}$ & $\begin{array}{l}-0.04 \\
(0.04)\end{array}$ & $\begin{array}{l}-0.04 \\
(0.04)\end{array}$ & $\begin{array}{l}-0.06 \\
(0.06)\end{array}$ & $\begin{array}{l}-0.00 \\
(0.05)\end{array}$ \\
\hline courseprest & $\begin{array}{l}-0.02 \\
(0.03)\end{array}$ & $\begin{array}{c}0.00 \\
(0.03)\end{array}$ & $\begin{array}{l}-0.02 \\
(0.03)\end{array}$ & $\begin{array}{c}0.09 \\
(0.06)\end{array}$ & $\begin{array}{c}-0.08^{* *} \\
(0.04)\end{array}$ \\
\hline coursevoc & $\begin{array}{c}0.02 \\
(0.04)\end{array}$ & $\begin{array}{c}0.04 \\
(0.04)\end{array}$ & $\begin{array}{c}0.03 \\
(0.04)\end{array}$ & $\begin{array}{c}0.04 \\
(0.06)\end{array}$ & $\begin{array}{c}0.01 \\
(0.06)\end{array}$ \\
\hline rdfirm & -0.04 & -0.03 & -0.04 & -0.03 & -0.04 \\
\hline
\end{tabular}


size5099

size100249

size250999

size 1000

public

numemployers

osownf

osothf

osanal

osackn

osnegot

ospress

osalert

oscoord

ostime

oswoth

oscmean

oscompu

ossolut

osquest

ospres

oswrite

oslang

overskillnow

underskillnow $\begin{array}{lllll}(0.03) & (0.03) & (0.03) & (0.06) & (0.04)\end{array}$

$\begin{array}{lllll}-0.04 & -0.04 & -0.03 & -0.08 & 0.01\end{array}$

$\begin{array}{lllll}(0.06) & (0.06) & (0.06) & (0.11) & (0.08)\end{array}$

$\begin{array}{lllll}-0.02 & -0.01 & -0.01 & 0.05 & -0.04\end{array}$

$\begin{array}{lllll}(0.06) & (0.06) & (0.06) & (0.11) & (0.08)\end{array}$

$\begin{array}{lllll}0.02 & 0.04 & 0.04 & 0.16 * & -0.01\end{array}$

$\begin{array}{lllll}(0.05) & (0.05) & (0.05) & (0.08) & (0.07)\end{array}$

$\begin{array}{lllll}0.07 * & 0.06 & 0.07 * & 0.15 * * & 0.04\end{array}$

$\begin{array}{lllll}(0.04) & (0.04) & (0.04) & (0.07)\end{array}$

$\begin{array}{lllll}-0.06 * & -0.06 * & -0.06 * & 0.01 & -0.12 * * *\end{array}$

$\begin{array}{lllll}(0.03) & (0.03) & (0.03) & (0.06) & (0.04)\end{array}$

$\begin{array}{lllll}0.01 & 0.01 & 0.01 & 0.02 & 0.00\end{array}$

$\begin{array}{lllll}(0.01) & (0.01) & (0.01) & (0.02) & (0.01)\end{array}$

$\begin{array}{llll}-0.18^{*} & -0.14 & -0.09 & -0.32^{*}\end{array}$

$\begin{array}{llll}(0.11) & (0.11) & (0.15) & (0.17)\end{array}$

$\begin{array}{lll}0.19 & 0.22 & 0.26\end{array}$

$(0.19) \quad(0.18) \quad(0.16)$

$\begin{array}{llll}-0.17 * & -0.12 & -0.14 & -0.15\end{array}$

$\begin{array}{llll}(0.09) & (0.10) & (0.15) & (0.15)\end{array}$

$\begin{array}{llll}-0.10 & -0.09 & -0.11 & -0.08\end{array}$

$\begin{array}{llll}(0.11) & (0.11) & (0.21) & (0.15)\end{array}$

$\begin{array}{lll}0.23 & 0.27 & 0.15\end{array}$

$\begin{array}{lll}(0.22) & (0.19) & (0.36)\end{array}$

$\begin{array}{llll}0.01 & 0.02 & 0.09 & -0.05\end{array}$

$\begin{array}{llll}(0.14) & (0.14) & (0.19) & (0.21)\end{array}$

$\begin{array}{llll}0.08 & 0.05 & 0.16 & -0.06\end{array}$

$\begin{array}{llll}(0.20) & (0.21) & (0.25) & (0.41)\end{array}$

$\begin{array}{llll}0.06 & 0.02 & -0.32 & 0.13\end{array}$

$\begin{array}{llll}(0.17) & (0.18) & (0.43) & (0.20)\end{array}$

$\begin{array}{llll}-0.13 & -0.12 & 0.01 & -0.06\end{array}$

$\begin{array}{llll}(0.14) & (0.14) & (0.23) & (0.22)\end{array}$

$\begin{array}{llll}-0.22 & -0.26 * & -0.25 & -0.25\end{array}$

$\begin{array}{llll}(0.14) & (0.14) & (0.23) & (0.23)\end{array}$

$\begin{array}{llll}-0.24 & -0.20 & -0.15 & -0.30\end{array}$

$\begin{array}{llll}(0.22) & (0.23) & (0.41) & (0.29)\end{array}$

$\begin{array}{llll}0.16 * & 0.18 * * & 0.30 * * * & 0.14\end{array}$

$\begin{array}{llll}(0.09) & (0.09) & (0.08) & (0.13)\end{array}$

$\begin{array}{llll}-0.14 & -0.16 & 0.04 & -0.24\end{array}$

$\begin{array}{llll}(0.16) & (0.16) & (0.31) & (0.20)\end{array}$

$\begin{array}{llll}0.10 & 0.13 & 0.16 & 0.14\end{array}$

$\begin{array}{llll}(0.11) & (0.11) & (0.15) & (0.16)\end{array}$

$\begin{array}{llll}-0.12 & -0.09 & -0.18 & -0.04\end{array}$

$\begin{array}{llll}(0.11) & (0.11) & (0.22) & (0.15)\end{array}$

$\begin{array}{llll}-0.06 & -0.05 & 0.02 & -0.11\end{array}$

$\begin{array}{llll}(0.11) & (0.12) & (0.19) & (0.16)\end{array}$

$\begin{array}{llll}-0.07 & -0.09 & 0.27 * & -0.24 * *\end{array}$

$\begin{array}{llll}(0.10) & (0.10) & (0.14) & (0.12)\end{array}$

$-0.23 * * *$

$(0.05)$

$-0.01$
$-0.23 * * *$

$(0.05)$

$-0.01$
$-0.30 * * *$

$(0.09)$

0.00 


\begin{tabular}{|c|c|c|c|c|c|}
\hline & $(0.04)$ & & $(0.04)$ & $(0.06)$ & $(0.05)$ \\
\hline \multirow[t]{2}{*}{ overskilljob1 } & $0.07^{*}$ & & 0.07 & -0.03 & $0.14^{* *}$ \\
\hline & $(0.04)$ & & $(0.04)$ & $(0.07)$ & $(0.06)$ \\
\hline \multirow[t]{2}{*}{ underskilljob1 } & -0.05 & & -0.06 & -0.07 & -0.07 \\
\hline & $(0.04)$ & & $(0.04)$ & $(0.07)$ & $(0.06)$ \\
\hline \multirow[t]{2}{*}{ overednow } & -0.07 & & -0.07 & -0.13 & -0.06 \\
\hline & $(0.06)$ & & $(0.06)$ & $(0.10)$ & $(0.08)$ \\
\hline \multirow[t]{2}{*}{ overedjob1 } & -0.04 & & -0.04 & -0.02 & -0.06 \\
\hline & $(0.05)$ & & $(0.05)$ & $(0.08)$ & $(0.06)$ \\
\hline \multirow[t]{2}{*}{ underednow } & -0.03 & & -0.02 & 0.02 & -0.08 \\
\hline & $(0.07)$ & & $(0.07)$ & $(0.11)$ & $(0.11)$ \\
\hline \multirow[t]{2}{*}{ underedjob1 } & -0.13 & & -0.14 & -0.21 & -0.05 \\
\hline & $(0.10)$ & & $(0.10)$ & $(0.15)$ & $(0.16)$ \\
\hline Observations & 1056 & 1050 & 1050 & 402 & 641 \\
\hline
\end{tabular}


Table 9: Male wage equations with competency based overskilling controls

\begin{tabular}{|c|c|c|c|}
\hline VARIABLES & $\begin{array}{c}(1) \\
\text { Model }\end{array}$ & $\begin{array}{c}(2) \\
\text { Model } \\
\end{array}$ & $\begin{array}{c}(3) \\
\text { Model }\end{array}$ \\
\hline male & $\begin{array}{c}0.00 \\
(0.00)\end{array}$ & $\begin{array}{c}0.00 \\
(0.00)\end{array}$ & $\begin{array}{c}0.00 \\
(0.00)\end{array}$ \\
\hline labexp & $\begin{array}{c}0.01 * * * \\
(0.00)\end{array}$ & $\begin{array}{c}0.01 * * * \\
(0.00)\end{array}$ & $\begin{array}{c}0.01 * * * \\
(0.00)\end{array}$ \\
\hline age & $\begin{array}{c}0.01^{*} \\
(0.00)\end{array}$ & $\begin{array}{c}0.00 \\
(0.00)\end{array}$ & $\begin{array}{c}0.01 * \\
(0.00)\end{array}$ \\
\hline education & $\begin{array}{l}-0.04 \\
(0.13)\end{array}$ & $\begin{array}{l}-0.11 \\
(0.14)\end{array}$ & $\begin{array}{l}-0.04 \\
(0.13)\end{array}$ \\
\hline human & $\begin{array}{c}0.14 \\
(0.12)\end{array}$ & $\begin{array}{c}0.08 \\
(0.13)\end{array}$ & $\begin{array}{c}0.14 \\
(0.13)\end{array}$ \\
\hline social & $\begin{array}{c}0.14 \\
(0.13)\end{array}$ & $\begin{array}{c}0.06 \\
(0.14)\end{array}$ & $\begin{array}{c}0.12 \\
(0.13)\end{array}$ \\
\hline science & $\begin{array}{c}0.10 \\
(0.13)\end{array}$ & $\begin{array}{c}0.05 \\
(0.14)\end{array}$ & $\begin{array}{c}0.07 \\
(0.14)\end{array}$ \\
\hline agvet & $\begin{array}{l}-0.05 \\
(0.16)\end{array}$ & $\begin{array}{l}-0.11 \\
(0.17)\end{array}$ & $\begin{array}{l}-0.05 \\
(0.16)\end{array}$ \\
\hline health & $\begin{array}{c}0.18 \\
(0.17)\end{array}$ & $\begin{array}{c}0.20 \\
(0.18)\end{array}$ & $\begin{array}{c}0.19 \\
(0.17)\end{array}$ \\
\hline mast & $\begin{array}{c}0.11 \\
(0.08)\end{array}$ & $\begin{array}{l}0.16^{*} \\
(0.09)\end{array}$ & $\begin{array}{c}0.13 \\
(0.08)\end{array}$ \\
\hline first & $\begin{array}{c}0.23^{* * *} \\
(0.08)\end{array}$ & $\begin{array}{c}0.26 * * * \\
(0.09)\end{array}$ & $\begin{array}{c}0.22^{* *} \\
(0.09)\end{array}$ \\
\hline twoone & $\begin{array}{c}0.10^{* *} \\
(0.05)\end{array}$ & $\begin{array}{c}0.12^{* *} \\
(0.05)\end{array}$ & $\begin{array}{c}0.10^{* *} \\
(0.05)\end{array}$ \\
\hline unemp & $\begin{array}{l}-0.08^{*} \\
(0.05)\end{array}$ & $\begin{array}{c}-0.12^{* *} \\
(0.05)\end{array}$ & $\begin{array}{l}-0.08 \\
(0.05)\end{array}$ \\
\hline supervise & $\begin{array}{c}0.05 \\
(0.05)\end{array}$ & $\begin{array}{c}0.07 \\
(0.05)\end{array}$ & $\begin{array}{c}0.05 \\
(0.05)\end{array}$ \\
\hline fieldmatchnow & $\begin{array}{l}-0.12 \\
(0.08)\end{array}$ & $\begin{array}{l}-0.04 \\
(0.08)\end{array}$ & $\begin{array}{l}-0.12 \\
(0.08)\end{array}$ \\
\hline fieldrelatednow & $\begin{array}{c}0.01 \\
(0.06)\end{array}$ & $\begin{array}{l}0.11 * \\
(0.06)\end{array}$ & $\begin{array}{c}0.01 \\
(0.07)\end{array}$ \\
\hline fieldmatchjob1 & $\begin{array}{l}-0.00 \\
(0.09)\end{array}$ & $\begin{array}{c}0.02 \\
(0.09)\end{array}$ & $\begin{array}{l}-0.01 \\
(0.09)\end{array}$ \\
\hline fieldrelatedjob1 & $\begin{array}{c}-0.15^{* *} \\
(0.06)\end{array}$ & $\begin{array}{c}-0.14^{* *} \\
(0.06)\end{array}$ & $\begin{array}{c}-0.16^{* *} \\
(0.07)\end{array}$ \\
\hline hours & $\begin{array}{c}0.02^{* * *} \\
(0.00)\end{array}$ & $\begin{array}{c}0.02 * * * \\
(0.00)\end{array}$ & $\begin{array}{c}0.02 * * * \\
(0.00)\end{array}$ \\
\hline coursemp & $\begin{array}{l}-0.00 \\
(0.05)\end{array}$ & $\begin{array}{l}-0.01 \\
(0.05)\end{array}$ & $\begin{array}{l}-0.01 \\
(0.05)\end{array}$ \\
\hline courseprest & $\begin{array}{l}0.08^{*} \\
(0.05)\end{array}$ & $\begin{array}{c}0.13^{* * *} \\
(0.05)\end{array}$ & $\begin{array}{l}0.09^{*} \\
(0.05)\end{array}$ \\
\hline coursevoc & $\begin{array}{c}0.00 \\
(0.05)\end{array}$ & $\begin{array}{c}0.04 \\
(0.05)\end{array}$ & $\begin{array}{c}0.00 \\
(0.05)\end{array}$ \\
\hline
\end{tabular}




\begin{tabular}{|c|c|c|c|}
\hline rdfirm & $\begin{array}{l}-0.03 \\
(0.04)\end{array}$ & $\begin{array}{c}0.01 \\
(0.05)\end{array}$ & $\begin{array}{l}-0.03 \\
(0.04)\end{array}$ \\
\hline \multirow[t]{2}{*}{ size5099 } & 0.05 & 0.00 & 0.04 \\
\hline & $(0.09)$ & $(0.09)$ & $(0.09)$ \\
\hline \multirow{2}{*}{ size100249 } & 0.07 & 0.03 & 0.05 \\
\hline & (0.09) & $(0.09)$ & $(0.09)$ \\
\hline \multirow[t]{2}{*}{ size250999 } & 0.06 & 0.06 & 0.07 \\
\hline & $(0.08)$ & (0.09) & $(0.08)$ \\
\hline \multirow[t]{2}{*}{ size1000 } & $0.22 * * *$ & $0.20 * * *$ & $0.23 * * *$ \\
\hline & $(0.06)$ & $(0.06)$ & $(0.06)$ \\
\hline \multirow{2}{*}{ public } & $-0.18 * * *$ & $-0.21 * * *$ & $-0.19 * * *$ \\
\hline & $(0.05)$ & $(0.05)$ & $(0.05)$ \\
\hline \multirow[t]{2}{*}{ numemployers } & 0.01 & 0.01 & 0.01 \\
\hline & $(0.01)$ & $(0.01)$ & $(0.01)$ \\
\hline \multirow[t]{2}{*}{ osownf } & & $-0.27 * *$ & -0.16 \\
\hline & & $(0.12)$ & $(0.12)$ \\
\hline \multirow[t]{2}{*}{ osothf } & & -0.16 & -0.01 \\
\hline & & $(0.21)$ & $(0.20)$ \\
\hline \multirow[t]{2}{*}{ osanal } & & -0.07 & -0.06 \\
\hline & & $(0.12)$ & $(0.12)$ \\
\hline \multirow[t]{2}{*}{ osackn } & & -0.12 & -0.01 \\
\hline & & $(0.16)$ & $(0.15)$ \\
\hline \multirow[t]{2}{*}{ osnegot } & & -0.15 & -0.08 \\
\hline & & $(0.72)$ & $(0.69)$ \\
\hline \multirow[t]{2}{*}{ ospress } & & -0.04 & 0.02 \\
\hline & & $(0.17)$ & $(0.16)$ \\
\hline \multirow[t]{2}{*}{ osalert } & & 0.32 & 0.21 \\
\hline & & $(0.26)$ & $(0.25)$ \\
\hline \multirow[t]{2}{*}{ oscoord } & & -0.32 & -0.17 \\
\hline & & $(0.30)$ & $(0.29)$ \\
\hline \multirow[t]{2}{*}{ ostime } & & -0.13 & -0.06 \\
\hline & & $(0.17)$ & $(0.17)$ \\
\hline \multirow[t]{2}{*}{ oswoth } & & -0.21 & -0.10 \\
\hline & & $(0.18)$ & $(0.17)$ \\
\hline \multirow[t]{2}{*}{ osmob } & & -0.59 & -0.36 \\
\hline & & $(0.55)$ & $(0.53)$ \\
\hline \multirow[t]{2}{*}{ oscmean } & & 0.00 & -0.06 \\
\hline & & $(0.31)$ & $(0.29)$ \\
\hline \multirow[t]{2}{*}{ osauth } & & -0.24 & 0.06 \\
\hline & & $(0.33)$ & $(0.32)$ \\
\hline \multirow[t]{2}{*}{ oscompu } & & 0.12 & 0.21 \\
\hline & & $(0.15)$ & $(0.14)$ \\
\hline \multirow[t]{2}{*}{ ossolut } & & 0.03 & 0.03 \\
\hline & & $(0.25)$ & $(0.24)$ \\
\hline \multirow[t]{2}{*}{ osquest } & & $-0.31^{* *}$ & $-0.27 * *$ \\
\hline & & $(0.14)$ & $(0.14)$ \\
\hline ospres & & 0.06 & 0.08 \\
\hline & & $(0.16)$ & $(0.15)$ \\
\hline oswrite & & -0.17 & -0.13 \\
\hline & & $(0.17)$ & $(0.16)$ \\
\hline
\end{tabular}




\begin{tabular}{lccc} 
oslang & & 0.17 & 0.12 \\
overskillnow & & $(0.17)$ & $(0.16)$ \\
& $\left(0.15^{* *}\right.$ & & $-0.14^{* *}$ \\
underskillnow & 0.06 & & $(0.07)$ \\
& $(0.05)$ & & 0.07 \\
overskilljob1 & -0.05 & & $(0.05)$ \\
& $(0.06)$ & & -0.03 \\
underskilljob1 & -0.07 & & $(0.06)$ \\
& $(0.06)$ & & -0.09 \\
overednow & $-0.31^{* * *}$ & & $-0.06)$ \\
& $(0.07)$ & & $(0.08)$ \\
overedjob1 & $-0.15^{* *}$ & & $-0.12 *$ \\
& $(0.06)$ & & $(0.06)$ \\
underednow & -0.05 & & -0.02 \\
& $(0.09)$ & & $(0.09)$ \\
underedjob1 & 0.13 & & 0.13 \\
& $(0.11)$ & & $(0.11)$ \\
Constant & $6.37 * * *$ & $6.40^{* * *}$ & $6.37 * *$ \\
& $(0.23)$ & $(0.25)$ & $(0.24)$ \\
& & & \\
Observations & 392 & 392 & 392 \\
R-squared & 0.50 & 0.46 & 0.51 \\
\hline
\end{tabular}


APPENDIX

\section{Summary Statistics}

\begin{tabular}{l|cc|cc|cc}
\multicolumn{2}{c}{ All Employees } & Males & \multicolumn{3}{c}{ Females } \\
\hline Variable & Mean & Std. Dev. & Mean & Std. Dev. & Mean & Std. Dev. \\
wage & & & & & & \\
overednow & 2659.85 & 1350.15 & 2899.85 & 1398.41 & 2509.69 & 1302.71 \\
underednow & 0.14 & 0.35 & 0.17 & 0.38 & 0.13 & 0.33 \\
overedjob1 & 0.06 & 0.23 & 0.07 & 0.26 & 0.04 & 0.21 \\
underedjob1 & 0.36 & 0.48 & 0.36 & 0.48 & 0.36 & 0.48 \\
& 0.03 & 0.18 & 0.05 & 0.21 & 0.02 & 0.14 \\
overskillnow & 0.14 & 0.35 & 0.18 & 0.38 & 0.12 & 0.32 \\
underskill $\sim$ w & 0.26 & 0.44 & 0.31 & 0.46 & 0.23 & 0.42 \\
overskillj 1 & 0.33 & 0.47 & 0.33 & 0.47 & 0.33 & 0.47 \\
underskill 1 & 0.21 & 0.41 & 0.25 & 0.43 & 0.18 & 0.39 \\
& & & & & & \\
male & 0.38 & 0.49 & 1.00 & 0.00 & 0.00 & 0.00 \\
labexp & 50.83 & 12.60 & 50.42 & 12.89 & 51.08 & 12.44 \\
age & 29.15 & 6.09 & 29.15 & 6.17 & 29.17 & 6.07 \\
education & 0.26 & 0.44 & 0.16 & 0.37 & 0.33 & 0.47 \\
human & 0.33 & 0.47 & 0.34 & 0.47 & 0.33 & 0.47 \\
social & 0.19 & 0.39 & 0.25 & 0.43 & 0.15 & 0.36 \\
science & 0.06 & 0.24 & 0.14 & 0.35 & 0.01 & 0.10 \\
agvet & 0.02 & 0.15 & 0.04 & 0.20 & 0.01 & 0.11 \\
health & 0.06 & 0.25 & 0.04 & 0.21 & 0.07 & 0.26 \\
& & & & & & \\
mast & 0.08 & 0.26 & 0.09 & 0.29 & 0.06 & 0.25 \\
first & 0.09 & 0.28 & 0.09 & 0.28 & 0.09 & 0.29 \\
twoone & 0.49 & 0.50 & 0.40 & 0.49 & 0.55 & 0.50 \\
unemp & 0.35 & 0.48 & 0.35 & 0.48 & 0.34 & 0.48 \\
supervise & 0.48 & 0.50 & 0.50 & 0.50 & 0.46 & 0.50 \\
fieldmatch W & 0.25 & 0.43 & 0.24 & 0.43 & 0.26 & 0.44 \\
fieldrelat $\sim \mathrm{W}$ & 0.41 & 0.49 & 0.42 & 0.49 & 0.41 & 0.49 \\
fieldmatch 1 & 0.20 & 0.40 & 0.19 & 0.39 & 0.20 & 0.40 \\
fieldrelat 1 & 0.32 & 0.47 & 0.34 & 0.47 & 0.31 & 0.46 \\
coursemp & 0.29 & 0.45 & 0.32 & 0.47 & 0.27 & 0.44 \\
courseprest & 0.47 & 0.50 & 0.44 & 0.50 & 0.48 & 0.50 \\
coursevoc & 0.27 & 0.44 & 0.28 & 0.45 & 0.26 & 0.44 \\
hours & & & & & & \\
sdfirm & 0.09 & 0.28 & 0.07 & 0.26 & 0.09 & 0.29
\end{tabular}




\begin{tabular}{l|ll|ll|ll} 
size250999 & 0.14 & 0.34 & 0.11 & 0.31 & 0.15 & 0.36 \\
size1000 & 0.45 & 0.50 & 0.50 & 0.50 & 0.42 & 0.49 \\
public & 0.47 & 0.50 & 0.37 & 0.48 & 0.54 & 0.50 \\
numemployers & 2.62 & 2.94 & 2.56 & 2.18 & 2.65 & 3.34 \\
& & & & & & \\
familynew & 0.10 & 0.30 & 0.05 & 0.22 & 0.12 & 0.32 \\
securenew & 0.26 & 0.44 & 0.19 & 0.39 & 0.30 & 0.46 \\
earnnew & 0.07 & 0.25 & 0.06 & 0.24 & 0.06 & 0.23 \\
learnnew & 0.24 & 0.43 & 0.21 & 0.41 & 0.25 & 0.43 \\
statusnew & 0.06 & 0.23 & 0.05 & 0.23 & 0.05 & 0.22 \\
usefulnew & 0.20 & 0.40 & 0.15 & 0.35 & 0.23 & 0.42 \\
leisnew & 0.17 & 0.37 & 0.15 & 0.35 & 0.17 & 0.38 \\
careernew & 0.17 & 0.38 & 0.18 & 0.39 & 0.16 & 0.37 \\
autonnew & 0.17 & 0.38 & 0.14 & 0.35 & 0.18 & 0.38 \\
challnew & 0.19 & 0.39 & 0.15 & 0.36 & 0.21 & 0.41
\end{tabular}




\section{Data Appendix}

Lwage

Overednow:

Underednow:

Overedjob1:

Underedjob1:

Overskillnow:

Underskillnow:

Overskilljob1:

Underskilljob1:

Male:

Labex

age:

Education:

Human:

Social:

Science:

Agvet:

Health:

Mast:

First:

Twoone:

Supervise:

Fieldmatchnow:

Fieldrelatednow:

Fieldmatchjob1:

Fieldrelatedjob1:

Coursemp:
Gross monthly earnings in main employment logged.

Dummy variable takes value 1 if overeducated in current job and zero otherwise

Dummy variable takes value 1 if undereducated in current job and zero otherwise

Dummy variable takes value 1 if overeducated in first job and zero otherwise

Dummy variable takes value 1 if undereducated in first job and zero otherwise

Dummy variable takes value 1 if overskilled in current job and zero otherwise

Dummy variable takes value 1 if underskilled in current job and zero otherwise

Dummy variable takes value 1 if overskilled in first job and zero otherwise

Dummy variable takes value 1 if underskilled in first job and zero otherwise

Dummy variable takes value 1 if Male and zero otherwise

Number of months employed since graduation

Age in years

Dummy variable takes value 1 if main field of study was Education and zero otherwise

Dummy variable takes value 1 if main field of study was Humanities and zero otherwise

Dummy variable takes value 1 if main field of study was Social Science and zero otherwise

Dummy variable takes value 1 if main field of study was Science and zero otherwise

Dummy variable takes value 1 if main field of study was Agriculture / Veterinary and zero otherwise

Dummy variable takes value 1 if main field of study was Education and zero otherwise

Dummy variable takes value 1 if possessed a Masters degree and zero otherwise

Dummy variable takes value 1 if possessed a First Class degree and zero otherwise

Dummy variable takes value 1 if possessed an Upper Second degree and zero otherwise

Dummy variable takes value 1 if supervised staff members and zero otherwise

Dummy variable takes value 1 if current job matched exclusively to field of study and zero otherwise

Dummy variable takes value 1 if current job matched on own or a related field of study and zero otherwise

Dummy variable takes value 1 if first job matched exclusively to field of study and zero otherwise

Dummy variable takes value 1 if first job matched on own or a related field of study and zero otherwise

Dummy variable takes value 1 if employers were familiar with course and zero otherwise 
Courseprest:

Coursevoc:

Hours:

RDfirm:

Size5099:

Size100249:

Size250999:

Size1000:

Size1000:

Numemployers:

Familynew

Securenew

Earnnew

Learnnew

Statusnew

Usefulnew

Leisnew

Careernew

Autonew

Challnew

Osownf:

Osothf:

Osanal:

Osack:

Osonegot:

Ospress:

Osalert:
Dummy variable takes value 1 if course was academically prestigious and zero otherwise

Dummy variable takes value 1 if course was vocationally and zero otherwise

Regular contract hours per week

Dummy variable takes value 1 if employed in a research intensive firm and zero otherwise

Dummy variable takes value 1 if employed in a firm with 50 to 99 workers and zero otherwise

Dummy variable takes value 1 if employed in a firm with 100 to 249 workers and zero otherwise

Dummy variable takes value 1 if employed in a firm with 250 to 999 workers and zero otherwise

Dummy variable takes value 1 if employed in a firm with over 1000 workers and zero otherwise

Dummy variable takes value 1 if employed in a public sector organisation and zero otherwise

Number of employers since graduation

Dummy variable if puts high emphasis on family work / balance and employed in a job with high level of work / family balance

Dummy variable if puts high emphasis on job security and employed in a job with high level of job security

Dummy variable if puts high emphasis on high earnings and employed in a job with high level of high earnings

Dummy variable if puts high emphasis on learning and employed in a job with high level of learning

Dummy variable if puts high emphasis on social status and employed in a job with high level of social status

Dummy variable if puts high emphasis on societal value and employed in a job with high level of societal value

Dummy variable if puts high emphasis on work / leisure balance and employed in a job with high level of work / leisure balance

Dummy variable if puts high emphasis on career prospects and employed in a job with high level of career prospects

Dummy variable if puts high emphasis on autonomy and employed in a job with high level of autonomy

Dummy variable if puts high emphasis on new challenges and employed in a job with high level of new challenges

Dummy variable takes value 1 if overskilled in own field and zero otherwise

Dummy variable takes value 1 if overskilled in another field and zero otherwise

Dummy variable takes value 1 if overskilled in analytical thinking and zero otherwise

Dummy variable takes value 1 if overskilled in ability to acquire new knowledge and zero

Dummy variable takes value 1 if overskilled in ability to negotiate effectively and zero otherwise

Dummy variable takes value 1 if overskilled in ability to perform well under pressure and zero otherwise

Dummy variable takes value 1 if overskilled in alertness to new opportunities and zero otherwise 
Oscoord:

Ostime:

Oswoth:

Osmob:

Oscmean:

Osauth:

Oscompu:

Ossolut:

Osquest:

Ospres:

Oswrite:

Oslang:
Dummy variable takes value 1 if overskilled in ability to coordinate activities and zero otherwise

Dummy variable takes value 1 if overskilled in ability to use time effectively and zero otherwise

Dummy variable takes value 1 if overskilled in ability to work productively with others and zero otherwise

Dummy variable takes value 1 if overskilled in ability to mobilize the capabilities of thers and zero otherwise

Dummy variable takes value 1 if overskilled in ability to make your meaning clear to others and zero otherwise

Dummy variable takes value 1 if overskilled in ability to assert your authority and zero otherwise

Dummy variable takes value 1 if overskilled in ability to use computers and zero otherwise

Dummy variable takes value 1 if overskilled in ability to come up with new ideas and solutions and zero otherwise

Dummy variable takes value 1 if overskilled in ability to question yours and others ideas and zero otherwise

Dummy variable takes value 1 if overskilled in ability to present ideas / products to others and zero otherwise

Dummy variable takes value 1 if overskilled in ability to write reports memos or documents and zero otherwise

Dummy variable takes value 1 if overskilled in ability to write and speak in a foreign language and zero otherwise 


\section{References}

1. Allen J., Badillo-Amador L. and van der Velden R., Wage Effects of JobWorker Mismatches: Heterogeneous Skills or Institutional Effects, ROA, University of Maastricht, September, 2006.

2. Badillo-Amador L., Lopez Nicolas A. and Vila Lladosa L., Education and Competence Mismatches: Job Satisfaction Consequences for Workers, Rect@ , 16(1)), 2008, 104.

3. Battu H., Belfield C.R. and Sloane P.J., Overeducation Among Graduates: A Cohort View, Education Economics, 17(1), 1999, 21-38.

4. Bauer T., Educational Mismatch and Wages: A Panel Analysis, Economics of Education Review, 21, 2002, 221-229.

5. Brennan J., Overview Report to HEFCE on the Flexible Professional in the Knowledge Society, Centre for Higher Education Research and Information (CHERI), Open University, November, 2008.

6. Card, D. E. \& Krueger, A.B. Myth and Measurement: The New Economics of the Minimum Wage. Princeton: Princeton University Press, New Jersey USA,1995.

7. Chevalier A., Measuring Overeducation, Economica, 70(3), 2003, 509-531.

8. Chevalier A. and Lindley J., Overeducation and the Skills of UK Graduates, Journal of the Royal Statistical Society, Series A, 172(2), 2009, 307-338.

9. Dolton P.J. and Silles M.A., The Effects of Overeducation on Earnings in the Graduate Labour Market, Economics of Education Review, 27, 2008, 125-139.

10. Dolton P.J. and Vignoles A., The Incidence and Effects of Overeducation in the UK Graduate Labour Market, Economics of Education Review, 19(2), 2000, 179-198

11. Fleming C.M. and Kler P., I'm Too Clever for this Job: A Bivariate Probit Analysis on Overeducation and Job Satisfaction in Australia, Applied Economics, 40(9), 2007, 1123-1138.

12. Gottschalk P. and Hansen M., Is the Proportion of College Workers in NonCollege Jobs Increasing?, Journal of Labor Economics, 21, 2003, 449-471.

13. Grazier S., O’Leary N.C. and Sloane P.J., Graduate Employment in the UK: An Application of the Gottschalk-Hansen Model, IZA Discussion Paper no. 3618, Bonn, 2008.

14. Green F. and McIntosh S., Is There a Genuine Under-utilisation of Skills Amongst the Over-qualified?, Applied Economics, 39, 2007, 427-439. 
15. Green F. and Zhu Y., Overqualification, Job Dissatisfaction and Increasing Dispersion in the Returns to Graduate Education, University of Kent, Department of Economics, Discussion Paper KDPE 08/03, January 2009.

16. McGuinness S. and Wooden M., Overskilling, Job Insecurity and Career Mobility, Industrial Relations, 48(2), April, 2009, 265-286.

17. Rosen S., Learning and Experience in the Labour Market, Journal of Human Resources, 7(3), 1972, 326-342.

18. Rosenbaum P.R., Observational Studies, Springer-Verlag, Germany, 2002.

19. Sicherman N. and Galor O., A Theory of Career Mobility, Journal of Political Economy, 98(1), 1990, 169-192. 